Canadian Journal of Fisheries and Aquatic Sciences

Canadian Science Publishing

Journal canadien des sciences halieutiques et aquatiques

\title{
Predator-prey interactions influenced by a dynamic river plume
}

\begin{tabular}{|r|l|}
\hline Journal: & Canadian Journal of Fisheries and Aquatic Sciences \\
\hline Manuscript ID & cjfas-2016-0302.R2 \\
\hline Danuscript Type: & Article \\
\hline Complete List of Authors: & $\begin{array}{l}\text { Phillips, Elizabeth M.; University of Washington School of Aquatic and } \\
\text { Fishery Sciences } \\
\text { Horne, John K.; University of Washington, } \\
\text { Zamon, Jeannette E.; National Marine Fisheries Service - NOAA }\end{array}$ \\
\hline Keyword: & $\begin{array}{l}\text { PREDATOR-PREY INTERACTION < General, FORAGING < General, } \\
\text { COASTAL WATERS < Environment/Habitat, PELAGIC FISH < General, } \\
\text { ECOLOGY < General }\end{array}$ \\
\hline
\end{tabular}

SCHOLARONE

Manuscripts 
1 i. Title:

Predator-prey interactions influenced by a dynamic river plume

3 ii. Authors:

4 Elizabeth M. Phillips, John K. Horne, Jeannette E. Zamon

5 iii. Affiliation and address:

E.M. Phillips and J.K. Horne: University of Washington, School of Aquatic and Fishery Sciences, Seattle, WA 98195, USA; emp11@uw.edu and jhorne@uw.edu J.E. Zamon: NOAA Fisheries, Point Adams Research Station, Hammond, OR 97121,

$9 \quad$ USA; jen.zamon@noaa.gov

10 iv. Corresponding author: USA

Phone: 206-221-5459

Email: emp11@uw.edu 
Running page head: Predator-prey interactions river plume

16 Abstract: Marine predator-prey interactions are often influenced by oceanographic processes

17 that aggregate prey. We examined density distributions of seabirds and prey fish associated with

18 the Columbia River plume to determine if variation in plume size (i.e., volume or surface area)

19 or location influences predator-prey interactions. Common murre (Uria aalge), sooty shearwater

20 (Ardenna grisea), and forage fish including northern anchovy (Engraulis mordax) and juvenile

21 salmon (Oncorhynchus spp.) occurred disproportionately in plume waters relative to adjacent

22 marine waters. Water clarity, an indicator of plume-influenced waters, was a significant

23 predictor of seabird and prey densities throughout the survey area. Murres occurred within 20

$24 \mathrm{~km}$ of the plume center of gravity $(\mathrm{CG})$ whereas shearwaters occurred $\sim 100 \mathrm{~km}$ north of the

25 plume CG, concurrent with highest densities of prey fish. Global indices of collocation (GIC)

26 were relatively low between murres and prey, compared to high values between shearwaters and

27 prey. Seabird densities were negatively correlated with plume size, suggesting that seabirds

28 concentrate in the plume to maximize foraging effort. We conclude that variation in Columbia

29 River plume size and location influences predator distributions, which increases predation

30 pressure on prey, including threatened salmonid species. 


\section{Introduction}

Predator-prey interactions are influenced by environmental conditions that affect a predator's ability to locate and capture prey (Wiens 1976). In the marine environment, predators often utilize physical features such as density fronts between water masses to locate prey in a relatively featureless environment (Decker and Hunt 1996; Hunt 1997; Ainley et al. 2009). Density fronts formed by freshwater flow into the ocean are important areas of biophysical coupling that aggregate zooplankton and larval fish (Govoni et al. 1989; Govoni and Grimes 1992; Morgan et al. 2005), making them available to planktivorous and piscivorous predators. Increased abundances of predators near river plumes (Ashford et al. 2013; Zamon et al. 2014; Kowalczyk et al. 2015) suggests that these physical features may be hotspots for predator-prey interactions.

Freshwater discharge from the Columbia River into marine waters of the northern California Current creates a large brackish plume (Hickey et al. 2010). During peak river flows, the plume can extend hundreds of kilometers along the Oregon and Washington coasts (Hickey et al. 2005). Its size (i.e., volume and surface area), location, and depth are primarily influenced by river flow (Burla et al. 2010), but seasonal winds, currents, and the semi-diurnal tidal cycle also contribute to variability in plume volume, surface area, and orientation relative to the coast (Hickey et al. 2005; Horner-Devine et al. 2009; Jay et al. 2009).

Columbia River flow and plume size typically peak during spring (April - June), which coincides with the downstream movement of approximately 133-143 million hatchery-reared and an unknown, but substantially smaller number of naturally-produced juvenile salmon (i.e., smolts) including coho (Oncorhynchus kisutch) and Chinook salmon (O. tshawytscha) (FPC 2015). Small schooling pelagic fishes including northern anchovy (Engraulis mordax), Pacific 
54 herring (Clupea pallasii), Pacific sardine (Sardinops sagax), and smelts (Osmeridae),

55 collectively called forage fish, also occur near the plume during spring and summer (Litz et al.

56 2013). In particular, anchovy aggregate and spawn in association with the plume (Richardson

57 1980; Litz et al. 2008), and are an important component of the prey community (Wiens and Scott

58 1975). Smolts are considered part of the forage fish community during their early marine

59 residence, as they are similar in length and appearance to many forage fish species (Hoar 1976),

60 overlap in space and time (Emmett et al. 2004, 2006; Orsi et al. 2007), and occur in the diets of

61 many predators (Lance and Thompson 2005; Gladics et al. 2014; Szoboszlai et al. 2015).

Recirculation of nutrients within the plume stimulates primary productivity and

63

64

65

66

67

68

69

70

71

72

73

74

75

76

zooplankton growth (Kudela et al. 2010), which supports fish and seabird populations (Hickey and Banas 2008). Plume waters can often be visually identified by color discontinuities across boundaries, and avian predators may orient to this contrast when searching for prey (Ainley 1977; Haney and Stone 1988; Cyrus 1991). Two seabird species, common murre (Uria aalge) and sooty shearwater (Ardenna grisea), are the most visible and numerous piscivores near the Columbia River plume, suggesting that these two species may be important predators in the area (Zamon et al. 2014). Approximately 532000 individual murres breed colonially along the Oregon and Washington coasts (Speich and Wahl 1989; Naughton et al. 2007; Fig. 1). Sooty shearwaters migrate annually from New Zealand during their non-breeding season (Shaffer et al. 2006), and a significant portion ( $\sim 10$ million individuals) occur in U.S. west coast shelf waters during boreal spring and summer (Ainley 1976; Briggs et al. 1987). Both avian species use pursuit-diving to capture and consume a variety of prey fish near the plume including northern anchovy, smelts, California market squid (Doryteuthis opalescens), and several species of juvenile salmon (Matthews 1983; Varoujean and Matthews 1983). 
High mortality of juvenile salmon during early marine residence is likely due to predation

78 (Pearcy 1992; Beamish and Mahnken 2001), but only a few studies have quantitatively examined

79 predator-prey interactions during this period (Beamish et al. 1992; Beamish and Neville 1995;

80 Emmett and Krutzikowsky 2008; Berejikian et al. 2016). Observations of elevated early marine

81 mortality of smolts during periods of low forage fish abundance (Fisher and Pearcy 1988; Pearcy

82 1992) prompted Emmett and Sampson (2007) to hypothesize that high abundances of forage

83 fishes would reduce predator encounter rates with juvenile salmonids, thereby reducing predation

84 on smolts. Both shearwaters and murres are opportunistic foragers (Matthews 1983; Chu 1984),

85 and the consumption of salmon by these two predators may be correlated with the availability of

86 other prey fish (Holling 1959; Angelstam et al. 1984). Higher densities of juvenile salmon occur

87 in the Columbia River plume during high river flows (Emmett et al. 2004), which also

corresponds to increasing densities of northern anchovy (Kaltenberg et al. 2010). Recent

89 research has linked river flow and plume volume to salmon survival (Miller et al. 2013; Brosnan

et al. 2014), but evidence to identify mechanisms of survival, including the influence of plume

91 dynamics on predators and prey, is not complete. Objectives of this study were to characterize

92 the avian predator and prey fish community associated with the Columbia River plume, to

93 determine spatial relationships between predators, prey, and the plume, and to assess the relative

94 importance of environmental and biological variables influencing potential seabird and prey

95 interactions.

\section{Materials and methods}

Data were collected during an ongoing ecosystem research program examining the ocean

99 ecology of juvenile salmon off the Washington and Oregon coasts (Brodeur et al. 2003). 
Running page head: Predator-prey interactions river plume

100 Hydrographic, trawl, acoustic, and seabird data were collected during daylight hours in May and

101 June 2010 to 2012 on three chartered commercial fishing vessels sampling along transects and at 102 fixed stations from northern Washington State to Newport, Oregon (Table 1).

103

104

105

106

107

108

109

110

111

112

113

114

115

116

117

118

119

120

\section{Transect Sampling}

Transects began 35-42 km offshore at dawn with the vessel traveling due east for $2 \mathrm{~h}$ at $\sim 5 \mathrm{~m} \mathrm{~s}^{-1}$ (Fig. 1). Seabird counts were made using standard strip transect survey methods (Tasker et al. 1984), where a single observer counted and identified all flying or sitting birds within $300 \mathrm{~m}$ of the vessel on the starboard side, from the bow to the beam of the ship in a $90^{\circ}$ arc, using a fixed-interval range finder (Heinemann 1981). Each bird sighting was called out to a recorder who entered the data into a computer linked with GPS to associate a time stamp and position to the bird sighting using SeeBird software (v 4.1.5.0; NOAA Fisheries Southwest

Fisheries Science Center, La Jolla, California, USA). Salinity and temperature of seawater was sampled every $2 \mathrm{~s}$ from a through-hull port at $3 \mathrm{~m}$ depth using a deck-mounted, flow-through, conductivity-temperature-depth instrument (hereafter, CTD; SBE 19, Sea-Bird Electronics Inc. ${ }^{1}$, Bellevue, Washington, USA; http://www.seabird.com/). To measure prey densities throughout the water column, continuous measurements of mean volume backscattering strength $\left(S_{v}\right.$; $d B$ re 1 $\mathrm{m}^{-1}$; MacLennan et al. 2002) were collected using EK60 or ES60 echosounders (Simrad, Kongsberg, Norway; http://www.simrad.com/) equipped with hull-mounted, split-beam transducers $\left(7^{\circ}\right.$ beamwidths measured at half power points) operating at $38 \mathrm{kHz}$ (Table 1). A pulse duration of $1.024 \mathrm{~ms}$ was transmitted at $2000 \mathrm{~W}$ at a sampling rate of $0.5 \mathrm{~Hz}$. With the

\footnotetext{
${ }^{1}$ Reference to trade names does not imply endorsement by the National Marine Fisheries Service, NOAA.
} 
121 exception of the May 2012 survey, echosounders were calibrated annually using a $38.1 \mathrm{~mm}$

122 tungsten carbide reference sphere following Foote et al. (1987).

\section{$124 \quad$ Station Sampling}

After transect sampling was completed, 5 to 8 fixed stations along the same transect were sampled, working from east to west (Fig. 1). The first sampling station was located at the $30 \mathrm{~m}$ depth contour, between 2 and $9 \mathrm{~km}$ offshore. Subsequent stations continued offshore at $\sim 9 \mathrm{~km}$ increments until the shelf break was reached (200 m depth), generally less than $55 \mathrm{~km}$ offshore. At each station, a profiling CTD (SBE 19plus; Sea-Bird Electronics Inc.) equipped with a transmissometer (C-Star; WET Labs, Philomath, Oregon, USA; http://www.wetlabs.com/) was deployed to a maximum depth of $100 \mathrm{~m}$ to record temperature, salinity, and transmissivity

132 through the water column. Zooplankton were sampled with a $0.60 \mathrm{~m}$ diameter Bongo net, fitted 133 with two black $335 \mu \mathrm{m}$ mesh nets and a flowmeter (General Oceanics or Tsurumi Seiki Co., 134 Ltd), towed obliquely from approximately 20-30 m deep to the surface. After the CTD and 135 zooplankton net were recovered at the surface, a $108 \mathrm{~m}$ long Nordic 264 rope trawl equipped 136 with $3.0 \mathrm{~m}$ Lite ${ }^{\circledR}$ trawl doors (NET Systems Inc., Bainbridge Island, Washington, USA; 137 http://www.net-sys.com/) was fished at the surface for $30 \mathrm{~min}$ at a rate of $1.5 \mathrm{~m} \mathrm{~s}^{-1}$ to collect 138 pelagic organisms in the upper $15-20 \mathrm{~m}$ of the water column. The net opening was $\sim 30 \times 20 \mathrm{~m}$ 139 (width $\mathrm{x}$ depth) when fishing, and contained variable mesh sizes ranging from $162.6 \mathrm{~cm}$ at the 140 net mouth to $8.9 \mathrm{~cm}$ at the cod-end, with a $6.1 \mathrm{~m}$ long, $0.8 \mathrm{~cm}$ mesh knotless liner sewn into the 141 cod-end. All items caught in the trawl were identified and recorded. Small catches were counted 142 in their entirety. For large catches, the total number of each species caught was counted or 143 estimated by weighing and counting a random subsample of individuals and scaling to the total 
144 weight of the catch. All juvenile salmonids were measured to the nearest millimeter (fork length, 145 FL) and preserved for later analysis. Up to 50 non-salmonids were measured, including fish (FL 146 or standard length, SL), squid (dorsal mantle length, DML) and large gelatinous species (bell 147 diameter for medusa, BD). To measure prey densities in the water column during trawling, 148 continuous $\mathrm{S}_{\mathrm{v}}$ measurements were collected using the same settings as during transect sampling. In addition to ship-based sampling, we obtained predicted daily values of plume volume, surface area, depth, and east-west/north-south orientation from the Center for Coastal Margin

151 Observation and Prediction (CMOP; db14 climatological atlas;

152 http://www.stccmop.org/datamart/virtualcolumbiariver). We also obtained average Columbia 153 River daily discharge records from Quincy, Oregon (river km 87; U.S. Geological Survey 154 surface water station 14246900; http://waterdata.usgs.gov/nwis).

\section{Data Processing}

\section{Acoustic Data Processing}

Acoustic data were processed using Echoview v 5.4 (http://www.echoview.com/). We

159 included the uncalibrated May 2012 acoustic data after comparing $\mathrm{S}_{\mathrm{v}}$ measurements from May 2012 to the calibrated data in 2010 and 2011 and finding no evidence of differing patterns in

161 amplitude. For data collected using an ES60 echosounder, the triangle wave error was removed 162 prior to data processing following Keith et al. (2005). Noise spikes and empty pings, where a 163 bottom signal was not received due to vessel motion, were manually removed. Ambient noise 164 levels were estimated using passive data collections in June $2012\left(-138.21 \mathrm{~dB} \mathrm{re} 1 \mathrm{~m}^{-1}\right.$ [hereafter $165 \mathrm{~dB}]$ ) and removed by linear subtraction (Nunnallee 1990; Watkins and Brierley 1996). Data 166 cells that did not meet a $6 \mathrm{~dB}$ signal-to-noise ratio threshold were excluded from analyses. Data 
167 from within $10 \mathrm{~m}$ of the surface were also excluded to account for transducer depth (4.25 m) and 168 twice the near-field range of the transducers $(5.44 \mathrm{~m})$.

Acoustic data were processed as an index of prey available to seabirds, as species identification of acoustic targets was not possible. To determine the volume backscatter 171 threshold (i.e., minimum $\mathrm{S}_{\mathrm{v}}$ value), we calculated the expected target strength of an anchovy at $17238 \mathrm{kHz}$ based on the expected minimum and maximum fork length of anchovy caught in our 173 trawl (50 and $200 \mathrm{~mm}$ ) using the target strength to length conversion equation from Demer et al. 174 (2011). The corresponding target strength range (-62.1 dB to $-50.1 \mathrm{~dB})$ was used to calculate 175 expected $\mathrm{S}_{\mathrm{v}}$ values of a single anchovy occurring in $1 \mathrm{~m}^{3}$ of water from 10 to $70 \mathrm{~m}$ depth. The 176 estimated $S_{v}$ for a $200 \mathrm{~mm}$ anchovy ranged from $-39.27 \mathrm{~dB}$ to $-60.61 \mathrm{~dB}$, with a median $\mathrm{S}_{\mathrm{v}}$ value 177 of $-55.31 \mathrm{~dB}$. The estimated $\mathrm{S}_{\mathrm{v}}$ value for a $50 \mathrm{~mm}$ anchovy ranged from $-51.27 \mathrm{~dB}$ to $-72.61 \mathrm{~dB}$, 178 with a median value of $-67.31 \mathrm{~dB}$. Based on these calculations, the minimum $\mathrm{S}_{\mathrm{v}}$ value was set to $179-60 \mathrm{~dB}$ throughout the water column. The $-60 \mathrm{~dB}$ threshold allowed us to remove backscatter 180 attributed to non-fish organisms such as krill, and is corroborated by previous studies of forage

181 fish in the region that used similar thresholds: $-60 \mathrm{~dB}$ at $38 \mathrm{kHz}$ (Kaltenberg and Benoit-Bird 182 2009), $-58.5 \mathrm{~dB}$ at $38 \mathrm{kHz}$ when "considerable quantities of small, non-hake scatterers were encountered" (Wilson et al. 2000; Fleischer et al. 2005). A maximum $\mathrm{S}_{\mathrm{v}}$ value was not set as we 184 were interested in large aggregations of forage fish that may be near the surface and available to 185 piscivorous seabirds. To exclude backscatter from adult hake, we limited our analyses to 186 observations in the upper $70 \mathrm{~m}$ of the water column, similar to other acoustic surveys of forage 187 fish in the region (Demer et al. 2011; Zwolinski et al. 2012). This depth also matches the general 188 diving range of sooty shearwaters and common murres (Piatt and Nettleship 1985; Weimerskirch 189 and Sagar 1996; Shaffer et al. 2009). Using the $-60 \mathrm{~dB}$ threshold, all $\mathrm{S}_{\mathrm{v}}$ measurements were 
190 vertically integrated from $10 \mathrm{~m}$ below the surface to $70 \mathrm{~m}$ depth, and horizontally either in $300 \mathrm{~m}$

191 intervals for the transect data, or along the full length of the trawling distance for station

192 sampling. Acoustic data were then scaled and reported as nautical area scattering coefficients

$193\left(\mathrm{~s}_{\mathrm{A}} ; \mathrm{m}^{2} \mathrm{nmi}^{-2}\right.$; MacLennan et al. 2002), indexed in space and time.

\section{Transect Data Processing}

Counts of birds sitting on the water surface were categorized as common murre, sooty

197 shearwater, or other seabird species. To estimate seabird associations with the plume and

198 potential prey, we analyzed seabirds that were sitting on the water surface or observed feeding

199 and excluded birds flying through the area, as birds in flight are not directly associated with the

200 location sampled (van Franeker 1994). Because strip transect census methods assume that all

201 sitting seabirds are detected within the area surveyed (Gaston and Smith 1984; van Franeker

202 1994), unaltered counts were used to estimate densities in $300 \mathrm{~m}^{2}$ increments along the survey

203 track. Continuous measures of surface salinity, surface temperature, and $\mathrm{s}_{\mathrm{A}}$ were matched by

204 time and location to seabird data using ArcMap 10.1 (ESRI, Redlands, California, USA).

\section{Station Data Processing}

207 To examine patterns in temperature, salinity, and density, we estimated thermocline, halocline, 208 and pycnocline depths by finding the largest point-to-point difference in $1 \mathrm{~m}$ averaged CTD

209 downcast values. Zooplankton data were summarized by total biomass at each station

210 (organisms $\mathrm{m}^{-3}$ ), because species-specific identifications are difficult to make for all plankton

211 species (C.A. Morgan, Oregon State University, Newport, Oregon, personal communication,

212 2015). Species-specific trawl catches were standardized to fish $\mathrm{km}^{-1}$ by dividing the number of 
213 fish caught by the distance between the start- and endpoints of the tow as determined by GPS

214 (mean: $3.3 \pm 0.7 \mathrm{~km}, \mathrm{SD})$. In instances where a trawl was repeated at the same station $(\mathrm{n}=13)$,

215 the average catch of the two samples was used for analyses. To delineate potential prey of

216 seabirds, catches were partitioned using known species and species groups consumed by

217 common murres (Varoujean and Matthews 1983; Nevins 2004) and sooty shearwaters (Baltz and

218 Morejohn 1977; Chu 1984). To ensure that appropriate size fish were included as prey and to

219 allow for variation in prey shapes (e.g., body depth versus length), we used a maximum of 250

$220 \mathrm{~mm}$ FL or DML for all potential prey species, corresponding to twice the standard deviation of

221 FL reported by Nevins (2004) for Pacific sardine consumed by common murres. We did not use

222 a minimum prey length as murres and shearwaters consume a range of prey sizes including larval

223 and juvenile life stages of marine organisms (Lance and Thompson 2005; Szoboszlai et al.

224 2015). All potential non-salmonid prey were categorized as alternative prey, and all salmon

$225 \leq 250 \mathrm{~mm}$ FL were categorized as juvenile salmon. To account for life history variation in length

226 at ocean entry for Chinook salmon, we used FL and month of capture to classify juveniles as

227 either subyearling or yearling based on known length-based age classes from scale analysis and

228 tagging studies (Pearcy and Fisher 1990; Fisher and Pearcy 1995). In May, subyearling fish had

229 FL $\leq 120 \mathrm{~mm}$, and yearlings had FL between 121-250 mm. In June, subyearling fish had FL

$230 \leq 140 \mathrm{~mm}$, and yearlings had FL between 141-250 mm. To assess co-occurrence of different

231 prey groups, trawl catch data were categorized to determine the number of trawls that contained

232 only alternative prey, only juvenile salmon, or both prey groups in the same sample. We also

233 calculated the ratio of juvenile salmon to total prey caught in each trawl. Species that were not

234 considered seabird prey items (e.g., jellyfish, adult salmon) were categorized as non-prey and

235 used to quantify total biomass sampled by the trawl. Shannon's diversity index (Magurran 1988) 
Running page head: Predator-prey interactions river plume

236 was calculated for the catch in each trawl. Catch (fish $\mathrm{km}^{-1}$ ) estimated from the surface trawl and 237 density estimates from acoustic backscatter were treated as separate variables for all analyses, as 238 there was no relationship between these two measures of fish abundance (Spearman's correlation, $239 \rho=-0.012, \mathrm{p}=0.857)$.

To facilitate comparisons of seabird densities with station samples of prey, seabird counts were summed and assigned to the nearest station, using one half the distance between stations as

242 the breakpoint. We addressed the time mismatch between transect seabird counts and

243 subsequent station trawl sampling (average: $4 \mathrm{~h}$; range: $30 \mathrm{~min}$ to $13 \mathrm{~h}$ ) by calculating

244 Spearman's correlation values between the aggregated seabird count data and seabird counts

245 collected opportunistically during station sampling in 2011 and 2012. There was a significant 246 relationship between murre $\left(\rho=0.70, \mathrm{p}=1.102 \times 10^{-13}\right)$ and shearwater $(\rho=0.40, \mathrm{p}=0.0002)$

247 density estimates, indicating no apparent bias in relative seabird abundance between transect 248 surveys and station sampling.

\section{Data Analysis}

To characterize seabird and prey communities associated with the Columbia River plume, 252 we examined intra- and inter-annual variation in river discharge, plume volume, plume surface 253 area, and seabird and fish abundance (fish $\mathrm{km}^{-1}$ and $\mathrm{s}_{\mathrm{A}}$ ) using Kruskall-Wallis tests and Dunn's 254 multiple comparison test when differences were detected (Zar 1999). Spatial pattern analyses 255 were accomplished by plotting all geospatial data in ArcMap using North America Albers equal256 area conic projection. CMOP data was converted from Oregon State Plane coordinates to 257 latitude and longitude. We horizontally interpolated $3 \mathrm{~m}$ salinity values measured at each station using ordinary kriging (Cressie 1993). The mixing of low-salinity recirculating plume waters 
259

260

261

262

263

264

265

266

267

268

269

270

271

272

273

274

275

276

277

278

279

280

and high-salinity coastal water creates multiple vertical and horizontal gradients (Horner-Devine et al. 2009; Jay et al. 2009), making plume boundaries difficult to define. We used a 28 practical salinity unit (psu) maximum following Burla et al. (2010) for analyses, but depict the plume surface area using halopycnals of tidal ( $<21 \mathrm{psu})$, recirculating (21-26 psu), and far-field plume waters (26-32.5 psu; Horner-Devine et al. 2009) to illustrate the complexity of the plume's horizontal structure.

The total survey area was defined by the northern and southernmost transects, and the eastern and westernmost stations sampled in each survey. Interpolated surface salinity values were used to calculate plume area within the total survey area. To validate our methods, we compared the calculated plume area values from interpolated data to the average predicted surface area values from CMOP model outputs for each survey and found an overall deviance of only $17 \mathrm{~km}^{2}$ between the two methods, confirming that our calculations were consistent.

To determine if predators or prey use the plume disproportionately to available area, we categorized each observation as inside ( $3 \mathrm{~m}$ salinity $\leq 28 \mathrm{psu}$ at the time of observation) or outside ( $>28 \mathrm{psu})$ the plume, and calculated proportions of seabirds and prey in each area. We focused on the horizontal surface plume as an indicator of overall areal extent, although subsurface $(>3 \mathrm{~m})$ structure of the river plume may be much more complex (Horner-Devine et al. 2009). Observed proportions of predators and prey in the plume were subtracted from expected proportions, defined as the proportion of plume area in the total calculated survey area during each cruise. If seabirds and prey were using the plume proportionate to available area, then differences between observed and expected values would be zero. We also calculated average density of seabirds, juvenile salmon, alternative prey, and acoustic backscatter inside and outside 
Running page head: Predator-prey interactions river plume

281 the plume based on. We compared the distribution of densities inside and outside the plume

282

283

284

285

286

287

288

289

290

291

292

293

294

295

296

297

298

299

300

301

302

303

using Mann-Whitney $U$ tests with an alpha value of 0.05 for significance tests.

Relationships between log-transformed seabird density estimates, log-transformed fish

catch, $\mathrm{s}_{\mathrm{A}}$, and plume size were explored using linear regression. We calculated the average plume volume and surface area for each survey from daily values obtained from CMOP model outputs. Because plume volume and surface area are correlated $(\rho=0.90, \mathrm{p}=0.015)$, we used average surface area as the explanatory variable in regression models of seabird density, as we hypothesized that air-borne seabirds show a stronger response to areal extent of the plume. We used plume volume in regression models for in-water prey. We also used predicted daily locations of the plume centroid from CMOP model outputs to estimate the overall geographic center of gravity $(\mathrm{CG})$ and inertia (defined as dispersion around the $\mathrm{CG}$ ) of the plume for each survey (Bez and Rivoirard 2001; Woillez et al. 2007, 2009). We verified our analyses by confirming visually that the estimated plume CG fell within the interpolated plume surface area calculated from CTD casts. We also calculated CG and inertia of seabirds, juvenile salmon, and alternative prey, and compared these to the size and location of the river plume for each survey. The Euclidean distance between the plume CG and each seabird species was compared among surveys using ANOVA (Zar 1999). We also measured the Euclidean distance between each predator and prey $\mathrm{CG}$ to estimate $\triangle \mathrm{CG}$ and calculate a global index of collocation (GIC; Woillez et al. 2007) for each survey using the R package RGeostats (Renard et al. 2015). The GIC calculates the extent to which two populations are geographically distinct, by comparing the distance between their CGs and respective inertias (Woillez et al. 2007). GIC values range between 0 , where each population is concentrated at a single but different location, and 1 , where the two CGs coincide and the inertias are non-negative. For this study, a GIC value greater than 
304 305

or equal to the $75^{\text {th }}$ percentile of calculated GIC values $(0.888)$ was considered indicative of high spatial overlap between predator and prey.

To assess the relative importance of environmental and biological variables influencing seabird and prey density distributions, we fit murre and shearwater density, alternative prey, and juvenile salmon catches to generalized linear models (GLM; McCullagh and Nelder 1989), using individual stations as the sampling unit. We used a priori model development to generate individual GLMs based on hypothesized relationships between seabirds, prey, and the environment (Burnham and Anderson 2002; Kutner et al. 2004). Six sets of GLMs were used to evaluate: murre density throughout the survey area (Model 1), shearwater density throughout the survey area (Model 2), alternative prey density throughout the survey area (Model 3), juvenile salmon density throughout the survey area (Model 4), murre density within the plume (Model 5), and shearwater density within the plume (Model 6). Each model set included combinations of environmental and biological covariates, and we tested candidate models for each GLM (Table 5). Covariates were evaluated for collinearity using variance inflation factors (VIF) and removed when VIF values exceeded 2 (Burnham and Anderson 2002). For Models 1 and 2, halocline depth, rather than pycnocline, was used because these covariates were collinear and we were primarily interested in the direct influence of plume depth on seabirds. For Models 3 and 4, we included temperature and zooplankton density in addition to salinity and water clarity, as these variables were hypothesized to influence forage fish and juvenile salmon distributions. Models 5 and 6 included only biological covariates, as we hypothesized that once seabirds had located the plume, their densities would no longer relate to environmental characteristics describing plume habitat. To account for interspecific attraction among seabirds, we included an estimate of other seabird species densities at each station in all seabird models. To account for documented 
327 patterns of increased abundances of seabirds nearshore (Menza et al. 2016), we included the

328 distance to shore of each station, measured as the straight-line distance along transect to land, as

329 a geospatial covariate. We used a negative binomial error distribution and log link with the R

330 package MASS (Venables and Ripley 2002) for all GLMs. This allowed us to model

331 overdispersed data without transformation, and accounted for high variability observed in trawl

332 and acoustic covariate data (McCullagh and Nelder 1989). We assumed no spatial

333 autocorrelation among bird densities, as the minimum distance between any two stations was 3.7

$334 \mathrm{~km}$, which is greater than the distance below which autocorrelation has been observed in seabirds

335 (Yen et al. 2006). Values of Akaike's Information Criterion corrected for small sample sizes

336 (AICc; Burnham and Anderson 2002; Kutner et al. 2004) were tabulated and compared among

337 intermediate models for each model set. The number of intermediate models evaluated for each

338 model set ranged from 5 to 15, and are not presented here. Candidate models with the lowest

$339 \Delta \mathrm{AICc}$ score and highest weight were chosen as the final model. Final model selection was

340 validated by visually inspecting deviance residual error structure (Zuur et al. 2009), and

341 calculating chi-squared statistics on the null and final model deviance (Burnham and Anderson

342 2002).

344 Results

A total of 17357 birds were counted along $1381 \mathrm{~km}$ of survey transects, and 303 stations

346 were sampled in May and June 2010, 2011, and 2012 (Table 1). Fifty-one percent of all sitting

347 or feeding birds counted were sooty shearwaters, and $34 \%$ were common murres (Table 2).

348 While 22 other avian species were observed, murres and shearwaters dominated counts in all

349 surveys. Density estimates were not significantly different between May and June for murres (U 
$350=4588, p=0.737)$ or shearwaters $(U=4450, p=0.478)$. Density estimates of murres were 351 significantly higher in $2010\left(20.6 \pm 75.4\right.$ birds $\left.\mathrm{km}^{-2}, \mathrm{H}=9.298, \mathrm{p}=0.010\right)$, compared to 2011 $352\left(7.0 \pm 22.1\right.$ birds km$\left.{ }^{-2}\right)$ and $2012\left(5.4 \pm 12.0\right.$ birds $\left.\mathrm{km}^{-2}\right)$. Shearwater densities were higher in 3532010 as well $\left(17.3 \pm 40.9\right.$ birds $\left.\mathrm{km}^{-2}\right)$, but not significantly different than any other year (overall 354 mean: $10.9 \pm 32.7$ birds $\left.\mathrm{km}^{-2} ; \mathrm{H}=1.015, \mathrm{p}=0.602\right)$. While murres and shearwaters were 355 observed on all transects, average densities of murres were highest on the Columbia River 356 transect $\left(13.9 \pm 27.4\right.$ birds $\left.\mathrm{km}^{-2}\right)$, near the nesting colony closest to the river mouth (Cape Meares 357 transect: $34.6 \pm 106.3$ birds $\mathrm{km}^{-2}$ ), and near the Yaquina Head, OR nesting colony (Newport 358 Hydrographic transect: $20.5 \pm 36.8$ birds $\mathrm{km}^{-2}$ ). Average densities of shearwaters were highest on transects north of the river mouth including Willapa Bay (19.8 \pm 42.2 birds km $\left.{ }^{-2}\right)$, Grays 360 Harbor $\left(25.5 \pm 54.2\right.$ birds $\left.\mathrm{km}^{-2}\right)$, and Queets River $\left(15.8 \pm 43.3\right.$ birds km$\left.{ }^{-2}\right)$. northern anchovy, 16\% other alternative prey species, and 5\% juvenile salmon. Frequency of occurrence (FO) of yearling Chinook salmon (62.5\%) and juvenile coho salmon (52.5\%) were the highest of all prey species, but average catch was low for yearling Chinook salmon $(2.1 \pm 2.9$ 365 fish $\left.\mathrm{km}^{-1}\right)$ and coho $\left(4.5 \pm 11.2\right.$ fish $\left.\mathrm{km}^{-1}\right)$ relative to alternative prey catches (Table 3). Average FO of the top six alternative prey species was low (12.7\%), but mean catch was higher and more

367 variable than any juvenile salmon species $\left(129.6 \pm 248.9\right.$ fish $\left.\mathrm{km}^{-1}\right)$. Juvenile salmon catch did not vary significantly among years $(H=5.917, \mathrm{p}=0.052)$ or between May and June surveys

369 within the same year $(\mathrm{U}=4426.5, \mathrm{p}=0.458)$. Juvenile salmon abundance was highest on transects adjacent to, or north of, the river mouth (Columbia River, Willapa Bay, Grays Harbor),

371 and lowest on transects in the south of the survey area. Alternative prey abundance measured by 372 surface trawls did not vary annually $(\mathrm{H}=5.089, \mathrm{p}=0.079)$, but was significantly greater in June 
373 compared to May $(U=3841, p=0.024)$. Highest forage fish catches occurred on the Grays

374 Harbor and Newport Hydrographic transects. Most $(63 \% ; n=146)$ trawl catches contained a

375 mix of both forage fish and juvenile salmon. In 54\% of mixed-prey species trawl catches, a

376 single forage fish species dominated the catch, typically northern anchovy, whereas salmon catch

377 composition ranged from a single species up to six salmonid species caught in the same trawl.

378 Prey fish density measured by acoustic backscatter $\left(\mathrm{s}_{\mathrm{A}}\right)$ did not vary annually $(\mathrm{U}=5.229, \mathrm{p}=$

379 0.073), but was greater in May compared to June $(U=2187, p=0.009)$. Highest $\mathrm{s}_{\mathrm{A}}$ values

380 occurred on the Columbia River, Willapa Bay, Grays Harbor, and La Push transects.

381

Mean river discharge was similar to the 10 year (2002-2012) average for the same May -

382 June period $\left(10058 \mathrm{~m}^{3} \mathrm{~s}^{-1}\right)$ in $2010\left(9831 \mathrm{~m}^{3} \mathrm{~s}^{-1}\right)$, but significantly greater than the average $(\mathrm{H}=$ 149.8, $\mathrm{p}<0.001)$ in $2011\left(15636 \mathrm{~m}^{3} \mathrm{~s}^{-1}\right)$ and in $2012\left(11336 \mathrm{~m}^{3} \mathrm{~s}^{-1}\right.$; Fig. 2). In May 2010,

384 average river discharge $\left(8664 \mathrm{~m}^{3} \mathrm{~s}^{-1}\right)$, estimated plume volume $\left(10.8 \mathrm{~km}^{3}\right)$, and surface area $(1$

$\left.385877 \mathrm{~km}^{2}\right)$ were lowest, whereas estimated plume volume was highest in May $2011\left(51.9 \mathrm{~km}^{3}\right)$,

386 when average discharge was highest $\left(16277 \mathrm{~m}^{3} \mathrm{~s}^{-1}\right)$. Highest surface area $\left(8738 \mathrm{~km}^{2}\right)$ occurred

387 in June 2011, when discharge was second highest $\left(14992 \mathrm{~m}^{3} \mathrm{~s}^{-1}\right)$. Overall, the plume area

388 ranged between 0.5 to $26 \%$ (mean: $17 \%$ ) of the total survey area.

Occupation of plume waters compared to adjacent marine waters was disproportionately

390 higher for murres, shearwaters, and all prey fish (Fig. 3). Overall mean densities of murres and

391 shearwaters were higher inside plume waters (murres: $16.1 \pm 21.0$ birds km${ }^{-2}$; shearwaters: 16.6

$392 \pm 16.7$ birds $\mathrm{km}^{-2}$ ) compared to mean densities in non-plume waters (murres: $9.8 \pm 8.7$ birds km$^{-}$

3932 ; shearwaters: $10.4 \pm 6.0$ birds $\mathrm{km}^{-2}$ ). We detected differences between plume and non-plume

394 density distributions for murres $(U=2069.5, p=0.002)$, but not for shearwaters $(U=2794.5, p=$

395 0.421). Similarly, mean densities of all prey fish were higher inside the plume (alternative prey 
396

397

398

399

400

401

402

403

404

405

406

407

408

409

410

411

412

413

414

415

416

417

418

fish: $284.4 \pm 613.2$ fish trawl ${ }^{-1}$; juvenile salmon: $6.9 \pm 7.6$ fish trawl $^{-1}$; acoustic prey: $380.7 \pm$ $408.2 \mathrm{~m}^{2} \mathrm{nmi}^{-2}$ ) than outside the plume (alternative prey fish: $74.3 \pm 82.8$ fish trawl $^{-1}$; juvenile salmon: $4.9 \pm 3.9$ fish $\operatorname{trawl}^{-1}$; acoustic prey: 192.9 $\pm 121.1 \mathrm{~m}^{2} \mathrm{nmi}^{-2}$ ). However, we did not detect statistically significant differences between plume and non-plume prey distributions (Mann-Whitney U tests; $\mathrm{p}>0.05$ ).

The density of murres and shearwaters occupying plume waters declined with plume surface area, although the pattern was significant only for murres $\left(F=13.6, p=0.021, R^{2}=0.72\right.$; Fig. 4a) and not shearwaters $\left(F=5.0, p=0.090, R^{2}=0.44\right.$; Fig. $\left.4 b\right)$. The density of forage fish and juvenile salmon caught in surface trawls, and acoustically detected prey, did not show a relationship to plume volume $\left(\mathrm{p}>0.05, \mathrm{R}^{2}<0.20\right.$; Fig. $\left.4 \mathrm{c}, \mathrm{d}\right)$. Highest bird densities (murres: 74.2 birds $\mathrm{km}^{-2}$, shearwaters: 68.1 birds $\mathrm{km}^{-2}$ ) in the plume were observed during the May 2010 survey, when plume surface area and volume were lowest. Lowest densities of murres (3.9 birds $\mathrm{km}^{-2}$ ) in the plume were observed in the May 2012 survey, when surface area was relatively high $\left(6219 \mathrm{~km}^{2}\right)$. Lowest densities of shearwaters $\left(7.3\right.$ birds $\left.\mathrm{km}^{-2}\right)$ were observed in the June 2011 survey, when plume area was highest $\left(8738 \mathrm{~km}^{2}\right)$, and no shearwaters were observed in the plume during the May 2011 survey, when plume area was second highest.

The $\Delta C G$ between plume locations observed during each survey was low $(40.2 \pm 29.0$ $\mathrm{km})$ and not significantly different between any of the surveys $(\mathrm{F}=2.47, \mathrm{p}=0.14)$, indicating that the location of the plume $\mathrm{CG}$ was relatively stable. The mean $\Delta \mathrm{CG}$ between murres and the plume CG was $20.8 \pm 11.7 \mathrm{~km}$, compared to $99.8 \pm 35.5 \mathrm{~km}$ for shearwaters. $\Delta \mathrm{CG}$ values between murres and the plume were not significantly different between surveys $(F=0.41, p=$ 0.56), but were, on average, less in May $(14.1 \mathrm{~km})$ than in June $(27.5 \mathrm{~km})$. Similarly, $\Delta \mathrm{CG}$ values between shearwaters and the plume were not significantly different between surveys $(\mathrm{F}=$ 
$4190.15, p=0.72)$, but were on average less in May $(85.3 \mathrm{~km})$ than in June $(114.3 \mathrm{~km})$. The spatial 420 distribution of CGs indicates that murres were consistently within the defined plume surface

421 ( $\leq 28 \mathrm{psu}$ ), with the exception of the June 2011 survey when they were in waters between 29 and

42230 psu (Fig. 5). In comparison, shearwater CGs were primarily outside the defined plume

423 surface $(>28 \mathrm{psu})$, near the northern edge of the plume boundary in waters between 28 and 30

424 psu, with the exception of May 2012 when they were located within recirculating plume waters

425 (21-26 psu) off the river mouth. The spatial distribution of juvenile salmonids as measured by

426 CG showed shifts in location between May and June surveys. Coho and Chinook salmon CGs

427 were primarily centered to the north of the plume in far-field waters, particularly during June

428 surveys when the pattern was more apparent (Fig. 5). Most alternative prey CGs were centered

429 near the northern portion of the plume, off Grays Harbor, except for northern anchovy, which

430 were often located near recirculating plume waters. The spatial distribution of anchovy shifted

431 from north-central of the river mouth in May, to the south and within plume waters in June.

The extent and size of the river plume also shifted between May and June, indicating shifting oceanographic conditions (Fig. 5). In May 2010, the river plume was oriented to the 434 north of the river mouth, typical of downwelling conditions (Horner-Devine et al. 2009; Hickey

435 et al. 2010). In May 2012 the river plume was bidirectional, which occurs when winds switch 436 from downwelling to upwelling-favorable during a survey (Hickey et al. 2005). When river 437 discharge and upwelling-favorable conditions increased in June, and during May 2011when 438 discharge was the highest observed, the plume was oriented to the south and offshore of the river 439 mouth.

GIC values between individual prey species and murres ranged between 0.11 and 0.99 , 
442 4). Highest GIC values occurred in May 2010 (mean: $0.85 \pm 0.16$ ), including multiple species of 443 juvenile salmon and forage fish. Average GIC values were slightly higher for murres in May $444(0.67 \pm 0.24)$ compared to June $(0.57 \pm 0.27)$. However, GIC values between anchovy, herring, 445 and murres were typically greater in June. In comparison, GIC values between shearwaters and 446 prey ranged between 0.10 and 0.99 , and at least three GIC values were $\geq 0.888$ on every survey, 447 with the exception of May 2012. GIC values were highest between shearwaters and prey 448 including juvenile coho and Chinook salmon, market squid, and surf smelt (Hypomesus 449 pretiosus). GIC values were highest in June 2010 (mean: $0.84 \pm 0.17$ ), followed by May 2010 450 (mean: $0.79 \pm 0.22$ ). GIC values between shearwaters and coho and yearling Chinook salmon 451 were high in nearly all surveys, whereas GIC values were only $\geq 0.888$ in June for subyearling 452 Chinook salmon (Table 4).

Murre and shearwater densities throughout the survey region were related to both 454 environmental and biological variables (Table 6). No candidate model with only biological or 455 environmental variables performed better than models with a combination of covariates. The 456 final model explaining murre density throughout the survey area (Model 1) demonstrated that 457 increases in murre densities were related to decreases in latitude, distance from shore, water 458 clarity, and acoustic backscatter, and increasing densities of other seabirds (i.e., local 459 enhancement; Table 6). The final model explaining shearwater density throughout the survey 460 area (Model 2) indicated that increases in shearwater densities were related to decreases in water 461 clarity and acoustic backscatter, and an increase in the density of other seabirds. Alternative 462 prey densities (Model 3) were related to decreases in water clarity and zooplankton density. 463 Similarly, juvenile salmon densities (Model 4) were related to decreases in water clarity, 464 zooplankton density, and temperature. Murre densities in the plume (Model 5) were related to 
Running page head: Predator-prey interactions river plume

465 increases in the density of other seabirds, acoustic backscatter, trawl diversity, and non-prey

466 density, and decreases in alternative prey and smolt density and the ratio of salmon to total prey.

467 Densities of shearwaters in the plume (Model 6) were related to decreases in acoustic backscatter 468 and alternative prey, and increases in smolt density and the ratio of salmon to total prey in trawl 469 catches.

471 Discussion

We demonstrate that variation in Columbia River plume size and location influences

473 spatial distributions of predators and prey. Seabirds and prey fish occurred disproportionately in

474 plume waters relative to adjacent waters. Decreased water clarity was a significant predictor of

475 predators and prey, confirming that enhanced plume-driven productivity supports upper trophic

476 levels. Shearwater and murre densities increased in the plume when plume size declined,

477 suggesting that seabirds concentrate in the plume to maximize foraging effort. Forage fish and

478 juvenile salmon catches did not vary with plume size, indicating that prey associated with the

479 plume are available to predators under varying plume conditions. Indices of collocation between

480 prey fish and seabirds were highest when plume volume and surface area were lowest,

481 demonstrating that reduced plume size increases prey encounter rates for foraging seabirds. Prey

482 occupying plume waters when volumes are low or surface areas are small may experience

483 increased predation pressure, which may be especially important for salmon residing in or

484 migrating through the plume during their transition from freshwater to the ocean. 
488 species can move along the coast in search of food may explain differences in results. Murres

489 are central place foragers (Orians and Pearson 1979) during spring and summer (April - August)

490 and the range over which breeding adult murres can forage is restricted to approximately $100 \mathrm{~km}$

491 radius of their colony to successfully incubate eggs, rear chicks, and fledge young (Decker and

492 Hunt 1996; Hatch et al. 2000; Davoren et al. 2003b). Although the colonies of origin and

493 proportion of actively breeding murres are unknown, high densities of breeding murres would be

494 expected, and were observed, near dense colonies on the Newport Hydrographic transect and on

495 the Cape Meares transect. However, similar densities were observed on the Columbia River

496 transect, suggesting that birds are transiting at least $80 \mathrm{~km}$ from colonies to the north or south of

497 the river mouth to forage in the plume. Memory and local enhancement are important for

498 visually foraging seabirds constrained to a colony (Davoren et al. 2003a, 2010; Regular et al.

499 2013; Tremblay et al. 2014), and turbid plume waters nearshore may be a predictable and

500 persistent feature that murres use to locate prey. This is supported by our finding that the murre

501 distributional center of gravity was within $20 \mathrm{~km}$ of the plume center, and greater murre densities

502 were related to decreasing water clarity. Murre densities were not, however, related to increased

503 prey densities in surface trawls, and indices of collocation with prey were relatively low. Murre

504 densities in the plume were related to acoustic backscatter deeper in the water column (10-70 m),

505 catches of non-prey items, and the diversity of organisms caught in surface trawls, including

506 adult salmon, sharks, and jellyfish. Once murres have located the plume, they may be cueing on

507 large organisms near the water surface as visual indicators of increased local prey densities (i.e.,

508 patches). Many large organisms also consume forage fish (Brodeur et al. 2014), so the

509 association of murres with non-prey and diverse trawl catches may indicate facilitation or

510 competition (Ainley et al. 2009; Toge et al. 2011; Sato et al. 2015). Given the disproportionately 
Running page head: Predator-prey interactions river plume

511 high occurrence of alternative prey and juvenile salmon in the plume, the relatively high prey

512 densities available under a variety of plume conditions and throughout the water column, and the

513 ability of murres to dive below the area sampled by the surface trawl to access prey, we propose

514 that murres employ a hierarchical foraging strategy by first detecting the turbid water of the river

515 plume or local aggregations of other seabirds, then locating large organisms near the surface of

516 the water, and finally initiating foraging on smaller pelagic prey. Increasing murre densities in

517 the plume as surface area declined further supports the idea that murres utilize the surface

518 manifestation of the plume as a predictable cue for locating prey, regardless of variability in

519 relative plume size or location of the plume.

520

Sooty shearwaters in the northern hemisphere are not constrained to colonies and are

521 expected to be more associated with areas of high prey availability (Ainley et al. 2009; Adams et

522 al. 2012; Lyday et al. 2015) compared to breeding mures. Yet even for unconstrained foragers,

523 the plume influences shearwater distributions, as demonstrated by the relationship between

524 increasing shearwater densities with declining water clarity and the consistent occurrence of

525 shearwaters $\sim 100 \mathrm{~km}$ to the north of the plume center. Global indices of collocation between

526 multiple species of alternative prey and shearwaters were high in the survey region, suggesting

527 that shearwaters occupying these waters have increased encounter rates with forage fish. This

528 result may be dependent on the scale of observation, as shearwater densities were not related to

529 local densities of forage fish measured acoustically or by the surface trawl. This may be due to

530 unresolved patchiness in forage fish distributions, availability to sampling gear during the day

531 (e.g., net avoidance), or survey design that did not adapt to dynamic plume conditions.

532 Shearwaters may be able to visually identify and track tidal fronts that form the northern plume

533 boundary (Zamon et al. 2014), which typically propagate northward and roughly perpendicular 
534 to the Washington coast (Horner-Devine et al. 2009; Jay et al. 2009). Tidal fronts are areas of

535 high productivity throughout the season (Hickey and Banas 2008; Jay et al. 2009), which

536 explains why so many forage fish species were located in the northern plume area. As river

537 discharge increases, plume volume and surface area also typically increase, and the plume 538 orientation shifts to the south (Burla et al. 2010). Thus, the relationship between declining 539 shearwater densities and plume area may relate to the shifting geographic location of the plume.

540 The location of shearwater CGs in waters between 28 and 32 psu also indicates that these 541 predators utilize a range of mixed plume waters.

542 Northern anchovy were the most abundant forage fish caught in our surface trawls, and 543 their distributions may be an important factor influencing predator-prey interactions associated 544 with the plume. Anchovy are a significant component of seabird diets in the northern California 545 Current (Wiens and Scott 1975; Varoujean and Matthews 1983), particularly during spawning 546 (mid-June - mid-August; Richardson 1980), when abundances are linked to increasing river

547 discharge and upwelling-favorable ocean conditions (Litz et al. 2008; Kaltenberg et al. 2010).

548 We observed a shift in anchovy density distributions between May and June surveys, with 549 increased densities and more southerly distributions in June, which may increase availability to 550 murres foraging in central plume waters. While estimates of collocation between murres and 551 anchovy were relatively low across all surveys, highest values were observed during June 552 surveys and in May 2011, when river flow was the highest observed. Declines observed in 553 murre density with increased plume surface area may indicate an interaction between river flow 554 and the location of spawning aggregations of anchovy, which may be closer to the productive 555 frontal boundaries of the plume. In comparison, shearwaters were only collocated with anchovy 556 in May 2010, when plume volume and surface area were the lowest observed and indices of 
557 collocation were high for numerous prey species. In most surveys, shearwaters were collocated

558 with other forage fish species (e.g., herring, squid, smelt), in addition to coho and Chinook

559 salmon that all occurred in high densities north of the river mouth. While anchovy are probably

560 an important factor influencing murre distributions in the plume, other forage fish species

561 including herring and smelt may also influence shearwater distributions.

Yearling coho and Chinook salmon were more evenly distributed in trawl catch samples compared to forage fish, suggesting that these salmonid species are available to predators under a

564 variety of plume conditions. The constant availability may sustain avian and other predators

565 during periods of proportionately lower abundances of forage fish. The relatively even

566 distribution of smolts may also explain the negative relationship of juvenile salmon and

567 zooplankton densities, which are concentrated at convergent zones in frontal regions of the

568 plume (Morgan et al. 2005). Variable marine migration rates of salmon stocks (Fisher et al.

569 2014; Teel et al. 2015) may infleunce the location and timing that smolts are vulnerable to

570 predators. Once in the ocean, yearling coho and Chinook salmon migrating along the

571 Washington coast were consistently collocated with shearwaters. Subyearling smolts that

572 migrate to the ocean later than yearlings were collocated with murres in May, and shearwaters

573 only in June after they began their migration north. The positive relationship between smolt

574 catches, the ratio of smolts to alternative prey, and shearwater densities indicates that the area

575 north of the river mouth may be an important "predator gauntlet" that juvenile salmon must pass

576 through during their northern migration.

Exposure to avian predators in the Columbia River plume, particularly during periods of

578 low river flow, could be a mechanism explaining variation in returns of adult salmon. Juvenile

579 salmon are thought to use river plumes as transitional habitats for osmoregulation, feeding, and 
580 refuge (Quinn 2005). Our results suggest that elevated predation mortality may also occur in

581 river plumes. Only $1-4 \%$ of smolts entering the ocean are estimated to spawn as adults

582 (Bradford 1995; Coronado and Hilborn 1998), with the majority of this mortality occurring

583 within weeks to months of entry into marine waters (Parker 1968; Beamish and Mahnken 2001).

584 The relationship between increasing plume volume and salmon survival documented by Miller et

585 al. (2013) may be partially explained by the decline in seabird densities we documented with 586 increasing plume size. Although Emmett et al. (2004) found that higher river flows resulted in

587 increased numbers of juvenile salmon in plume waters, a larger plume may reduce smolt

588 predation by increasing the total search area for shearwaters and murres foraging in the plume.

589 Avian predation of smolts in the lower Columbia River estuary by Caspian terns (Hydroprogne 590 caspia) and double-crested cormorants (Phalacrocorax auritus) is estimated at between 3 and 21

591 million smolts per year (Collis et al. 2001; Evans et al. 2012). Given that there is at least an 592 order of magnitude more murres ( 131 000; Speich and Wahl 1989; Suryan et al. 2012) and 593 shearwaters ( 2.2 million; Wiens and Scott 1975; Adams et al. 2012) than terns (12 500) and 594 cormorants (27 000; Roby et al. 2015), and that murres and shearwaters consume salmon in 595 similar proportions to terns and cormorants (Matthews 1983; Varoujean and Matthews 1983; J.E. 596 Zamon, NOAA Fisheries, Hammond, Oregon, unpublished data), juvenile salmonid mortality by 597 seabirds is certainly higher than currently estimated. To definitively address the impact of 598 seabird predation on salmonids associated with the Columbia River plume and to estimate avian 599 predation rates, data on smolt and alternative prey species composition, depth distribution, 600 abundance, and availability, concurrent with seabird diet samples over a range of plume 601 conditions are needed. 
Running page head: Predator-prey interactions river plume

Freshwater inputs to coastal ecosystems occur across land-sea interfaces around the world (Dai and Trenberth 2002). Plume patterns influencing predators and prey observed during this study may inform future research on the influence of a changing climate on ecological interactions in other river plumes (e.g., Fraser River, Canada), including increasing predation pressure during juvenile salmon outmigration (sensu Mote et al. 2003). Hydropower and storage dams have stabilized seasonal river flows and reduced annual discharge (Dai et al. 2009), and modified the size and orientation of the Columbia River plume (Ebbesmeyer and Tangborn 1992). As climate change impacts snowpack and subsequent freshwater runoff (Hamlet et al. 2007; Palmer et al. 2008), plume volumes may be further reduced. In the Pacific Northwest, earlier spring peak flows, and reduced spring and summer runoff volumes are expected in the Columbia River Basin (Hamlet and Lettenmaier 1999; Payne et al. 2004; Palmer et al. 2008). The lowest flows observed during our study occurred in 2010, but were greater than average daily flows in 2013-2015 (U.S. Geological Survey surface water station 14246900; http://waterdata.usgs.gov/nwis). Because of the enhanced productivity generated by nutrient input and recirculation, river plumes have been identified as potential refugia for juvenile and adult fish during periods of low ocean productivity (Litz et al. 2013). Our results show that river plumes are important areas for predator-prey interactions, and that changing environmental conditions have the potential to affect trophic interactions and energy flow in coastal food webs influenced by river plumes.

\section{Acknowledgements}

We thank the Bonneville Power Administration for supporting this research. The captains and crew of the $F / V$ Chellissa, $F / V$ Frosti, and $F / V$ Miss Sue were vital for data collections. 
625 Numerous scientific staff from NOAA's Northwest Fisheries Science Center Pt. Adams,

626 Montlake, and Newport facilities, as well as collaborators from Oregon State University's

627 Cooperative Institute for Marine Resources Studies assisted during surveys, and we are grateful

628 for their work and enthusiasm. We thank A. Baptista and C. Seaton for the CMOP data, and D.

629 Demer at NOAA's Southwest Fisheries Science Center for acoustic data in 2010 and 2011. K.

630 Fresh and two anonymous reviewers provided helpful comments on the manuscript. Lastly, we 631 remember our colleague, the late R. Emmett, who initiated and sustained these ocean surveys 632 with eternal enthusiasm, and who continues to inspire this work.

\section{References}

634

635

636

637

638

639

640

641

642

643

644

645

646

647

Adams, J., MacLeod, C., Suryan, R.M., Hyrenbach, K.D., and Harvey, J.T. 2012. Summer-time use of west coast US National Marine Sanctuaries by migrating sooty shearwaters (Puffinus griseus). Biol. Conserv. 156: 105-116. doi:10.1016/j.biocon.2011.12.032.

Ainley, D.G. 1976. The occurrence of seabirds in the coastal region of California. West. Birds 7(2): 33-68.

Ainley, D.G. 1977. Feeding methods in seabirds: a comparison of polar and tropical nesting communities in the eastern Pacific Ocean. In Adaptations within Antarctic ecosystems. Edited by G.A. Llano. Smithsonian Institution, Washington, DC. pp. 669-685.

Ainley, D.G., Dugger, K.D., Ford, R.G., Pierce, S.D., Reese, D.C., Brodeur, R.D., Tynan, C.T., and Barth, J.A. 2009. Association of predators and prey at frontal features in the California Current: competition, facilitation, and co-occurrence. Mar. Ecol. Prog. Ser. 389: 271-294. doi:10.3354/meps08153.

Angelstam, P., Lindström, E., and Widén, P. 1984. Role of predation in short-term population fluctuations of some birds and mammals in Fennoscandia. Oecologia 62(2): 199-208. 
Ashford, J.R., Ezer, T., and Jones, C.M. 2013. River discharge predicts spatial distributions of beluga whales in the Upper Cook Inlet, Alaska, during early summer. Polar Biol. 36(8): 1077-1087. doi:10.1007/s00300-013-1330-8.

Baltz, D.M., and Morejohn, G.V. 1977. Food habits and niche overlap of seabirds wintering on Monterey Bay, California. The Auk 94(3): 526-543. doi:10.2307/4085219.

Barrett, R.T., Camphuysen, K., Anker-Nilssen, T., Chardine, J.W., Furness, R.W., Garthe, S., Huppop, O., Leopold, M.F., Montevecchi, W.A., and Veit, R.R. 2007. Diet studies of seabirds: a review and recommendations. ICES J. Mar. Sci. 64(9): 1675-1691.

Beamish, R.J., and Neville, C.-E.M. 1995. Pacific salmon and Pacific herring mortalities in the Fraser River plume caused by river lamprey (Lampetra ayresi). Can. J. Fish. Aquat. Sci. 52(3): 644-650. doi:10.1139/f95-064.

Beamish, R.J., and Mahnken, C. 2001. A critical size and period hypothesis to explain natural regulation of salmon abundance and the linkage to climate and climate change. Prog. Oceanogr. 49(1-4): 423-437. doi:10.1016/S0079-6611(01)00034-9.

Beamish, R.J., Thomson, B.L., and McFarlane, G.A. 1992. Spiny dogfish predation on Chinook and coho salmon and the potential effects on hatchery-produced salmon. Trans. Am. Fish. Soc. 121(4): 444-455. doi:10.1577/1548-8659(1992)121<0444:SDPOCA>2.3.CO;2.

Berejikian, B.A., Moore, M.E., and Jeffries, S.J. 2016. Predator-prey interactions between harbor seals and migrating steelhead trout smolts revealed by acoustic telemetry. Mar. Ecol. Prog. Ser. 543: 21-35. doi:10.3354/meps11579.

Bez, N., and Rivoirard, J. 2001. Transitive geostatistics to characterise spatial aggregations with diffuse limits: an application on mackerel ichtyoplankton. Fish. Res. 50(1-2): 41-58. doi:10.1016/S0165-7836(00)00241-1. 
671 Bradford, M.J. 1995. Comparative review of Pacific salmon survival rates. Can. J. Fish. Aquat.

672

673

674

675

676

677

678

679

680

681

682

683

684

685

686

687

688

689

690

691

Sci. 52(6): 1327-1338. doi:10.1139/f95-129.

Briggs, K.T., Tyler, W.B., Lewis, D.B., and Carlson, D.R. 1987. Bird communities at sea off California, 1975-1983. Stud. Avian Biol. 11: 1-74.

Brodeur, R.D., Buchanan, J.C., and Emmett, R.L. 2014. Pelagic and demersal fish predators on juvenile and adult forage fishes in the California Current: spatial and temporal variations. CalCOFI Rep. 55: 96-116.

Brodeur, R.D., Myers, K.W., and Helle, J.H. 2003. Research conducted by the United States on the early ocean life history of Pacific Salmon. N. Pac. Anadr. Fish Comm. Bull. 3: 89131.

Brosnan, I.G., Welch, D.W., Rechisky, E.L., and Porter, A.D. 2014. Evaluating the influence of environmental factors on yearling Chinook salmon survival in the Columbia River plume (USA). Mar. Ecol. Prog. Ser. 496: 181-196. doi:10.3354/meps10550.

Burla, M., Baptista, A.M., Zhang, Y.L., and Frolov, S. 2010. Seasonal and interannual variability of the Columbia River plume: A perspective enabled by multiyear simulation databases. J. Geophys. Res.-Oceans 115: C00B16. doi:10.1029/2008jc004964.

Burnham, K.P., and Anderson, D. 2002. Model selection and multimodel inference. Springer New York. New York, NY

Chu, E.W. 1984. Sooty shearwaters off California: diet and energy gain. In Marine birds: their feeding ecology and commercial fisheries relationships. Special publication of the Canadian Wildlife Service. Ottawa, Canada. pp. 64-71. 
Claiborne, A.M., Miller, J.A., Weitkamp, L.A., Teel, D.J., and Emmett, R.L. 2014. Evidence for selective mortality in marine environments: the role of fish migration size, timing, and production type. Mar. Ecol. Prog. Ser. 515: 187-202. doi:10.3354/meps10963.

Collis, K., Roby, D.D., Craig, D.P., Ryan, B.A., and Ledgerwood, R.D. 2001. Colonial waterbird predation on juvenile salmonids tagged with passive integrated transponders in the Columbia River estuary: Vulnerability of different salmonid species, stocks, and rearing types. Trans. Am. Fish. Soc. 130(3): 385-396. doi:10.1577/15488659(2001)130<0385:CWPOJS>2.0.CO;2.

Cooney, R.T., Allen, J.R., Bishop, M.A., Eslinger, D.L., Kline, T., Norcross, B.L., Mcroy, C.P., Milton, J., Olsen, J., Patrick, V., Paul, A.J., Salmon, D., Scheel, D., Thomas, G.L., Vaughan, S.L., and Willette, T.M. 2001. Ecosystem controls of juvenile pink salmon (Onchorynchus gorbuscha) and Pacific herring (Clupea pallasi) populations in Prince William Sound, Alaska. Fish. Oceanogr. 10: 1-13. doi:10.1046/j.10546006.2001.00039.x.

Coronado, C., and Hilborn, R. 1998. Spatial and temporal factors affecting survival in coho salmon (Oncorhynchus kisutch) in the Pacific Northwest. Can. J. Fish. Aquat. Sci. 55(9): 2067-2077. doi:10.1139/198-090.

Cressie, N. 1993. Statistics for spatial data, revised edition. John Wiley \& Sons, Inc., Hoboken, NJ, USA. doi: 10.1002/9781119115151.

Cyrus, D.P. 1991. The influence of turbidity on the foraging behavior of little terns (Sterna albifrons) off the St Lucia Mouth, Zululand, South Africa. Mar. Ornithol. 19: 103-108.

Dai, A., Qian, T., Trenberth, K.E., and Milliman, J.D. 2009. Changes in continental freshwater discharge from 1948 to 2004. J. Clim. 22(10): 2773-2792. doi:10.1175/2008JCLI2592.1. 
715 716

717

718

719

720

721

722

723

724

725

726

727

728

729

730

731

732

733

734

735

Dai, A., and Trenberth, K.E. 2002. Estimates of freshwater discharge from continents: latitudinal and seasonal variations. J. Hydrometeorol. 3(6): 660-687. doi:10.1175/15257541(2002)003<0660:EOFDFC $>2.0 . \mathrm{CO} ; 2$.

Davoren, G.K., Garthe, S., Montevecchi, W.A., and Benvenuti, S. 2010. Influence of prey behaviour and other predators on the foraging activities of a marine avian predator in a low Arctic ecosystem. Mar. Ecol. Prog. Ser. 404: 275-287. doi:10.3354/meps08370.

Davoren, G.K., Montevecchi, W.A., and Anderson, J.T. 2003a. Search strategies of a pursuitdiving marine bird and the persistence of prey patches. Ecol. Monogr. 73(3): 463-481.

Davoren, G.K., Montevecchi, W.A., and Anderson, J.T. 2003b. Distributional patterns of a marine bird and its prey: habitat selection based on prey and conspecific behaviour. Mar. Ecol. Prog. Ser. 256: 229-242. doi: 10.3354/meps256229.

Decker, M.B., and Hunt, G.L. 1996. Foraging by murres (Uria spp) at tidal fronts surrounding the Pribilof Islands, Alaska, USA. Mar. Ecol. Prog. Ser. 139(1-3): 1-10.

Demer, D.A., Zwolinski, J.P., Byers, K.A., Cutter, G.R., Renfree, J.S., Sessions, T.S., and Macewicz, B.J. 2011. Acoustic-trawl surveys of Pacific sardine (Sardinops sagax) and other pelagic fishes in the California Current ecosystem: Part 1, Methods and an example application. Pac. Fish. Manag. Counc, Appendix C: Pacific Sardine Stock Assessment.

Ebbesmeyer, C.C., and Tangborn, W. 1992. Linkage of reservoir, coast, and strait dynamics, 1936-1990: Columbia River Basin, Washington Coast, and Juan de Fuca Strait. In Interdisciplinary Approaches in Hydrology and Hydrogeology. American Institute of Hydrology, St. Paul, MN. pp. 288-299. 
Emmett, R.L., Brodeur, R.D., and Orton, P.M. 2004. The vertical distribution of juvenile salmon (Oncorhynchus spp.) and associated fishes in the Columbia River plume. Fish. Oceanogr. 13(6): 392-402. doi:10.1111/j.1365-2419.2004.00294.x.

Emmett, R.L., Krutzikowsky, G.K., and Bentley, P. 2006. Abundance and distribution of pelagic piscivorous fishes in the Columbia River plume during spring/early summer 1998-2003: Relationship to oceanographic conditions, forage fishes, and juvenile salmonids. Prog. Oceanogr. 68(1): 1-26. doi:10.1016/j.pocean.2005.08.001.

Emmett, R.L., and Sampson, D.B. 2007. The relationships between predatory fish, forage fishes, and juvenile salmonid marine survival off the Columbia River: A simple trophic model analysis. CalCOFI Rep. 48: 92-105.

Emmett, R.L., and Krutzikowsky, G.K. 2008. Nocturnal feeding of pacific hake and jack mackerel off the mouth of the Columbia River, 1998-2004: implications for juvenile salmon predation. Trans. Am. Fish. Soc. 137(3): 657-676. doi:10.1577/T06-058.1.

Evans, A.F., Hostetter, N.J., Roby, D.D., Collis, K., Lyons, D.E., Sandford, B.P., Ledgerwood, R.D., and Sebring, S. 2012. Systemwide evaluation of avian predation on juvenile salmonids from the Columbia River based on recoveries of passive integrated transponder tags. Trans. Am. Fish. Soc. 141(4): 975-989. doi:10.1080/00028487.2012.676809.

Fisher, J.P., and Pearcy, W.G. 1988. Growth of juvenile coho salmon (Oncorhynchus kisutch) off Oregon and Washington, USA, in years of differing coastal upwelling. Can. J. Fish. Aquat. Sci. 45(6): 1036-1044. doi:10.1139/f88-127.

Fisher, J.P., and Pearcy, W.G. 1995. Distribution, migration, and growth of juvenile chinook salmon, Oncorhynchus tshawystcha, off Oregon and Washington. Fish Bull 93: 274-289. 
759 760

761

762

763

764

765

766

767

768

769

770

771

772

773

774

775

776

777

778

779

780

781

Fisher, J.P., Weitkamp, L.A., Teel, D.J., Hinton, S.A., Orsi, J.A., Farley, E.V., Morris, J.F.T., Thiess, M.E., Sweeting, R.M., and Trudel, M. 2014. Early ocean dispersal patterns of Columbia River Chinook and coho salmon. Trans. Am. Fish. Soc. 143(1): 252-272. doi:10.1080/00028487.2013.847862.

Fleischer, G.W., Cooke, K.D., Ressler, P.H., Thomas, R.E., de Blois, S.K., Hufnagle, L.C., Kronlund, A.R., Holmes, J.A., and Wilson, C.D. 2005. The 2003 integrated acoustic and trawl survey of Pacific hake, Merluccius productus, in U.S. and Canadian waters off the Pacific coast. U.S. Dept. Commer., NOAA Tech. Memo. NMFS-NWFSC-65, 45 p.

Foote, K.G., Knudsen, H.P., Vestnes, G., MacLennan, D.N., and Simmonds, E.J. 1987. Calibration of acoustic instruments for fish density estimation: a practical guide. ICES Coop. Res. Rep. 144, Copenhagen, Denmark.

van Franeker, J.A. 1994. A comparison of methods for counting seabirds at sea in the Southern Ocean. J. Field Ornithol. 65(1): 96-108. doi:10.2307/4513902.

FPC (Fish Passage Center). 2015. Fish Passage Center Annual Report. http://fpc.org/documents/annual_FPC_report/FPC2015_Annual_Report.pdf

Gaston, A.J., and Smith, G.E.J. 1984. The interpretation of aerial surveys for seabirds: some effects on behaviour. Occasional paper of the Canadian Wildlife Service Number 53.

Gladics, A.J., Suryan, R.M., Brodeur, R.D., Segui, L.M., and Filliger, L.Z. 2014. Constancy and change in marine predator diets across a shift in oceanographic conditions in the Northern California Current. Mar. Biol. 161(4): 837-851. doi:10.1007/s00227-013-2384-4.

Govoni, J.J., and Grimes, C.B. 1992. The surface accumulation of larval fishes by hydrodynamic convergence within the Mississippi River plume front. Cont. Shelf Res. 12(11): 12651276. 
782 783

Govoni, J.J., Hoss, D.E., and Colby, D.R. 1989. The spatial distribution of larval fishes about the Mississippi River plume. Limnol. Oceanogr. 34(1): 178-187.

Hamlet, A.F., and Lettenmaier, D.P. 1999. Effects of climate change on hydrology and water resources in the Columbia River basin. J. Am. Water Resour. Assoc. 35(6): 1597-1623. doi:10.1111/j.1752-1688.1999.tb04240.x.

Hamlet, A.F., Mote, P.W., Clark, M.P., and Lettenmaier, D.P. 2007. Twentieth-century trends in runoff, evapotranspiration, and soil moisture in the western United States. J. Clim. 20(8): 1468-1486. doi:10.1175/JCLI4051.1.

Haney, J.C., and Stone, A.E. 1988. Seabird foraging tactics and water clarity: Are plunge divers really in the clear? Mar. Ecol. Prog. Ser. 49(1-2): 1-9.

Hatch, S.A., Meyers, P.M., Mulcahy, D.M., and Douglas, D.C. 2000. Seasonal movements and pelagic habitat use of murres and puffins determined by satellite telemetry. The Condor 102(1): 145-154. doi:10.2307/1370415.

Heinemann, D. 1981. A range finder for pelagic bird censusing. J. Wildl. Manag. 45(2): 489493. doi:10.2307/3807930.

Hickey, B., and Banas, N. 2008. Why is the northern end of the California Current system so productive? Oceanography 21(4): 90-107. doi:10.5670/oceanog.2008.07.

Hickey, B., Geier, S., Kachel, N., and MacFadyen, A.F. 2005. A bi-directional river plume: The Columbia in summer. Cont. Shelf Res. 25(14): 1631-1656. doi: 10.1016/J.Csr.2005.04.010.

Hickey, B.M., Kudela, R.M., Nash, J.D., Bruland, K.W., Peterson, W.T., MacCready, P., Lessard, E.J., Jay, D.A., Banas, N.S., Baptista, A.M., Dever, E.P., Kosro, P.M., Kilcher, L.K., Horner-Devine, A.R., Zaron, E.D., McCabe, R.M., Peterson, J.O., Orton, P.M., 
805

806

807

808

809

810

811

812

813

814

815

816

817

818

819

820

821

822

823

824

825

826

827

Pan, J., and Lohan, M.C. 2010. River influences on shelf ecosystems: Introduction and synthesis. J Geophys Res 115: C00B17. doi:10.1029/2009jc005452.

Hoar, W.S. 1976. Smolt transformation: evolution, behavior, and physiology. J. Fish. Res. Board Can. 33(5): 1233-1252. doi:10.1139/f76-158.

Holling, C.S. 1959. The components of predation as revealed by a study of small-mammal predation of the European pine sawfly. Can. Entomol. 91(05): 293-320. doi:10.4039/Ent9129-7.

Horner-Devine, A.R., Jay, D.A., Orton, P.M., and Spahn, E.Y. 2009. A conceptual model of the strongly tidal Columbia River plume. J. Mar. Syst. 78(3): 460-475. doi: 10.1016/j.jmarsys.2008.11.025.

Hunt, G.L. 1997. Physics, zooplankton, and the distribution of least auklets in the Bering Sea a review. ICES J. Mar. Sci. 54(4): 600-607. doi:10.1006/jmsc.1997.0267.

Jay, D.A., Pan, J., Orton, P.M., and Horner-Devine, A.R. 2009. Asymmetry of Columbia River tidal plume fronts. J. Mar. Syst. 78(3): 442-459. doi: 10.1016/j.jmarsys.2008.11.015.

Kaltenberg, A., Emmett, R., and Benoit-Bird, K. 2010. Timing of forage fish seasonal appearance in the Columbia River plume and link to ocean conditions. Mar. Ecol. Prog. Ser. 419: 171-184. doi:10.3354/meps08848.

Kaltenberg, A.M., and Benoit-Bird, K.J. 2009. Diel behavior of sardine and anchovy schools in the California Current System. Mar. Ecol. Prog. Ser. 394: 247-262. doi: $10.3354 /$ meps 08252 .

Keith, G.J., Ryan, T.E., and Kloser, R.J. 2005. ES60Adjust.jar Java Software utility to remove a systematic error in Simrad ES60 data. CSIRO Marine and Atmospheric Research, Tasmania, Australia. 
Kowalczyk, N.D., Reina, R.D., Preston, T.J., and Chiaradia, A. 2015. Selective foraging within estuarine plume fronts by an inshore resident seabird. Mar. Ecosyst. Ecol. 2: 42. doi:10.3389/fmars.2015.00042.

Kudela, R.M., Horner-Devine, A.R., Banas, N.S., Hickey, B.M., Peterson, T.D., McCabe, R.M., Lessard, E.J., Frame, E., Bruland, K.W., Jay, D.A., Peterson, J.O., Peterson, W.T., Kosro, P.M., Palacios, S.L., Lohan, M.C., and Dever, E.P. 2010. Multiple trophic levels fueled by recirculation in the Columbia River plume. Geophys. Res. Lett. 37(L18607): 1-7. doi: 10.1029/2010g1044342.

Kutner, M., Nachtsheim, C., Neter, J., and Li, W. 2004. Applied linear statistical models, 5th edition. McGraw-Hill/Irwin, Chicago, Illinois.

Lance, M.M., and Thompson, C.W. 2005. Overlap in diets and foraging of common murres (Uria alge) and rhinoceros auklets (Cerorhinca monocerata) after the breeding season. The Auk 122(3): 887-901.

Litz, M.N.C., Emmett, R.L., Bentley, P.J., Claiborne, A.M., and Barceló, C. 2013. Biotic and abiotic factors influencing forage fish and pelagic nekton community in the Columbia River plume (USA) throughout the upwelling season 1999-2009. ICES J. Mar. Sci. 71: 5-18. doi:10.1093/icesjms/fst082.

Litz, M.N.C., Heppell, S.S., Emmett, R.L., and Brodeur, R.D. 2008. Ecology and distribution of the northern subpopulation of northern anchovy (Engraulis mordax) off the US west coast. CalCOFI Rep. 49: 167-182.

Lyday, S.E., Ballance, L.T., Field, D.B., and David Hyrenbach, K. 2015. Shearwaters as ecosystem indicators: Towards fishery-independent metrics of fish abundance in the California Current. J. Mar. Syst. 146: 109-120. doi:10.1016/j.jmarsys.2014.08.010. 
851 MacLennan, D.N., Fernandes, P.G., and Dalen, J. 2002. A consistent approach to definitions and 852 symbols in fisheries acoustics. ICES J. Mar. Sci. 59(2): 365-369. doi:10.1006/jmsc.2001.1158.

Magurran, A.E. 1988. Ecological diversity and its measurement. Croom Helm Ltd, Kent, UK.

Matthews, D. 1983. Feeding ecology of the common murre, Uria aalge, off the Oregon coast. M.Sc. thesis, University of Oregon, Eugene, Oregon.

857

McCullagh, P., and Nelder, J.A. 1989. Generalized linear models, 2nd edition. Chapman and Hall/CRC Monographs on Statistics \& Applied Probability 37.

Menza, C., Leirness, J., White, T., Winship, A.J., Kinlan, B., Kracker, L., Zamon, J.E., Ballance, L.T., Becker, E., Forney, K.A., Barlow, J., Adams, J., Pereksta, D., Pearson, S., Pierce, J., Jeffries, S.J., Calambokidis, J., Douglas, A., Hanson, B., Benson, S.R., and Antrim, L. 2016. Predictive mapping of seabirds, pinnipeds and cetaceans off the Pacific coast of Washington. NOAA Tech. Memo. NOS NCCOS 210, 96 p.

Miller, J.A., Teel, D.J., Baptista, A., Morgan, C.A., and Bradford, M. 2013. Disentangling bottom-up and top-down effects on survival during early ocean residence in a population of Chinook salmon (Oncorhynchus tshawytscha ). Can. J. Fish. Aquat. Sci. 70(4): 617629. doi:10.1139/cjfas-2012-0354.

Morgan, C.A., De Robertis, A., and Zabel, R.W. 2005. Columbia River plume fronts. I. Hydrography, zooplankton distribution, and community composition. Mar. Ecol. Prog. Ser. 299: 19-31. doi:10.3354/meps299019.

Mote, P.W., Parson, E.A., Hamlet, A.F., Keeton, W.S., Lettenmaier, D., Mantua, N., Miles, E.L., Peterson, D.W., Peterson, D.L., Slaughter, R., and Snover, A.K. 2003. Preparing for 
Running page head: Predator-prey interactions river plume

climatic change: The water, salmon, and forests of the Pacific Northwest. Clim. Change 61(1-2): 45-88. doi:10.1023/A:1026302914358.

Muir, W.D., Marsh, D.M., Sandford, B.P., Smith, S.G., and Williams, J.G. 2006. Posthydropower system delayed mortality of transported Snake River stream-type Chinook salmon: unraveling the mystery. Trans. Am. Fish. Soc. 135(6): 1523-1534. doi:10.1577/T06-049.1.

Naughton, M.B., Pitkin, D.J., Lowe, R.W., So, K.J., and Strong, C.S. 2007. Catalog of Oregon seabird colonies. USFWS Biol. Tech. Publ. BTP-R1009-2007.

Nevins, H.M. 2004. Diet, demography, and diving behavior of the common murre (Uria aalge) in central California. M.Sc. thesis, San Francisco State University, Moss Landing Marine Laboratories, Moss Landing, California.

Nunnallee, E.P. 1990. An alternative to thresholding during echo-integration data collection. Rapp. Procès-Verbaux La Réun. Cons. Int. Pour Explor. Mer 189: 92-94.

Orians, G.H., and Pearson, N.E. 1979. On the theory of central place foraging. In Analysis of Ecological Systems. Edited by D.J. Horn, R.D. Mitchell, and G.R. Stairs. Ohio State University Press, Columbus. pp. 154-177.

Orsi, J.A., Harding, J.A., Pool, S.S., Brodeur, R.D., Haldorson, L.J., Murphy, J.M., Moss, J.H., Farley, E.V., Sweeting, R.M., Morris, J.F.T., Trudel, M., Beamish, R.J., Emmett, R.L., and Fergusson, E.A. 2007. Epipelagic fish assemblages associated with juvenile Pacific salmon in neritic waters of the California Current and the Alaska Current. Am. Fish. Soc. Symp. 57: 105-155. 
894 895 896 897 898 899 900 901 902 903 904 905 906 907 908 909 910 911

912 913 914 915

Palmer, M.A., Reidy Liermann, C.A., Nilsson, C., Flörke, M., Alcamo, J., Lake, P.S., and Bond, N. 2008. Climate change and the world's river basins: anticipating management options. Front. Ecol. Environ. 6(2): 81-89. doi:10.1890/060148.

Parker, R.R. 1968. Marine mortality schedules of pink salmon of the Bella Coola River, central British Columbia. J. Fish. Res. Board Can. 25(4): 757-794. doi:10.1139/f68-068.

Payne, J.T., Wood, A.W., Hamlet, A.F., Palmer, R.N., and Lettenmaier, D.P. 2004. Mitigating the effects of climate change on the water resources of the Columbia River Basin. Clim. Change 62(1-3): 233-256. doi:10.1023/B:CLIM.0000013694.18154.d6.

Pearcy, W.G. 1992. Ocean ecology of north Pacific salmonids. Washington Sea Grant Program, Books in Recruitment Fishery Oceanography, University of Washington Press, Seattle.

Pearcy, W.G., and Fisher, J.P. 1990. Distribution and abundance of juvenile salmonids off Oregon and Washington, 1981-1985. NOAA Tech Rep NMFS 93.

Piatt, J.F., and Nettleship, D.N. 1985. Diving depths of four alcids. The Auk 102(2): 293-297.

Quinn, T.P. 2005. The behavior and ecology of Pacific salmon and trout. American Fisheries Society, University of Washington Press, Seattle.

Regular, P.M., Hedd, A., and Montevecchi, W.A. 2013. Must marine predators always follow scaling laws? Memory guides the foraging decisions of a pursuit-diving seabird. Anim. Behav. 86(3): 545-552. doi:10.1016/j.anbehav.2013.06.008.

Renard, D., Bez, N., Desassis, N., Beucher, H., Ors, F., and Laporte, F. 2015. RGeostats: The Geostatistical package [11.0.1]. MINES ParisTech. Available from cg.ensmp.fr/rgeostats. Richardson, S.L. 1980. Spawning biomass and early life of northern anchovy, Engraulis mordax, in the northern sub-population off Oregon and Washington. Fish. Bull. 78(4): 855-876. 
Running page head: Predator-prey interactions river plume

916

917

918

919

920

921

922

923

924

925

926

927

928

929

930

931

932

933

934

935

936

937

938

Roby, D.D., Collis, K., Lyons, D.E., Suzuki, Y., Loschl, P., Lawes, T., Bixler, K., Peck-

Richardson, A., Piggott, A., Bailey, O., McKinnon, H., Laws, A., Mulligan, J., Toomey, S., Munes, A., Schniedermeyer, N., Wilson, A., Smith, G., Saunders, K., Hanwacker, L., Horton, C., Evans, A.F., Cramer, B.M., Turecek, A., Payton, Q., Hawbecker, M., and Kuligowski, D.R. 2015. Research, monitoring, and evaluation of avian predation on salmonid smolts in the lower and mid $\square$ Columbia River. Bonneville Power Adm. USACE - Portland Dist. Grant Cty. PUD,Priest Rapids Coord. Comm. 2014 Annual Report.

Sato, N.N., Kokubun, N., Yamamoto, T., Watanuki, Y., Kitaysky, A.S., and Takahashi, A. 2015. The jellyfish buffet: jellyfish enhance seabird foraging opportunities by concentrating prey. Biol. Lett. 11(8): 20150358. doi:10.1098/rsbl.2015.0358.

Scheel, D., and Hough, K. 1997. Salmon fry predation by seabirds near an Alaskan hatchery. Mar. Ecol. Prog. Ser. 150: 35-48. doi:10.3354/meps150035.

Scheuerell, M.D., Zabel, R.W., and Sandford, B.P. 2009. Relating juvenile migration timing and survival to adulthood in two species of threatened Pacific salmon (Oncorhynchus spp.). J. Appl. Ecol. 46(5): 983-990. doi:10.1111/j.1365-2664.2009.01693.x.

Shaffer, S.A., Tremblay, Y., Weimerskirch, H., Scott, D., Thompson, D.R., Sagar, P.M., Moller, H., Taylor, G.A., Foley, D.G., Block, B.A., and Costa, D.P. 2006. Migratory shearwaters integrate oceanic resources across the Pacific Ocean in an endless summer. Proc. Natl. Acad. Sci. 103(34): 12799-12802. doi:10.1073/pnas.0603715103.

Shaffer, S.A., Weimerskirch, H., Scott, D., Pinaud, D., Thompson, D.R., Sagar, P.M., Moller, H., Taylor, G.A., Foley, D.G., Tremblay, Y., and Costa, D.P. 2009. Spatiotemporal habitat use by breeding sooty shearwaters Puffinus griseus. Mar. Ecol. Prog. Ser. 391: 209-220. doi: $10.3354 / \operatorname{meps} 07932$. 
939 940

941

942

943

944

945

946

947

948

949

950

951

952

953

954

955

956

957

958

959

960

961

Speich, S.M., and Wahl, T.R. 1989. Catalog of Washington seabird colonies. U.S. Fish Wildl. Serv. Biol. Rep. 88(6), 510 p.

Suryan, R.M., Phillips, E.M., So, K., Zamon, J.E., Lowe, R.W., and Stephensen, S.W. 2012. Marine bird colony and at-sea distributions along the Oregon coast: Implications for marine spatial planning and information gap analysis. Northwest Natl. Mar. Renew. Energy Cent. Rep. No 2.

Szoboszlai, A.I., Thayer, J.A., Wood, S.A., Sydeman, W.J., and Koehn, L.E. 2015. Forage species in predator diets: Synthesis of data from the California Current. Ecol. Inform. 29(1): 45-56. doi:10.1016/j.ecoinf.2015.07.003.

Tasker, M.L., Jones, P.H., Dixon, T., and Blake, B.F. 1984. Counting seabirds at sea from ships a review of methods employed and a suggestion for a standardized approach. Auk 101(3): $567-577$.

Teel, D.J., Burke, B.J., Kuligowski, D.R., Morgan, C.A., and Doornik, D.M.V. 2015. Genetic identification of Chinook salmon: Stock-specific distributions of juveniles along the Washington and Oregon coasts. Mar. Coast. Fish. 7(1): 274-300. doi:10.1080/19425120.2015.1045961.

Toge, K., Yamashita, R., Kazama, K., Fukuwaka, M., Yamamura, O., and Watanuki, Y. 2011. The relationship between pink salmon biomass and the body condition of short-tailed shearwaters in the Bering Sea: can fish compete with seabirds? Proc. R. Soc. Lond. B Biol. Sci. 278(1718): 2584-2590. doi:10.1098/rspb.2010.2345.

Tomaro, L.M., Teel, D.J., Peterson, W.T., and Miller, J.A. 2012. When is bigger better? Early marine residence of middle and upper Columbia River spring Chinook salmon. Mar. Ecol. Prog. Ser. 452: 237-252. doi:10.3354/meps09620. 
962 Tremblay, Y., Thiebault, A., Mullers, R., and Pistorius, P. 2014. Bird-borne video-cameras show

963

964

965

966

967

968

969

970

971

972

973

974

975

976

977

978

979

980

981

982

983

984

that seabird movement patterns relate to previously unrevealed proximate environment, not prey. PLoS ONE 9(2): e88424. doi:10.1371/journal.pone.0088424.

Varoujean, D., and Matthews, D. 1983. Distribution, abundance, and feeding habits of seabirds off the Columbia River, May-June, 1982. University of Oregon Institute of Marine Biology, Charleston, Oregon.

Venables, W.N., and Ripley, B.D. 2002. Modern applied statistics with S, Fourth Edition. Springer, New York, New York.

Watkins, J.L., and Brierley, A.S. 1996. A post-processing technique to remove background noise from echo integration data. ICES J. Mar. Sci. 53(2): 339-344. doi:10.1006/jmsc.1996.0046.

Weimerskirch, H., and Sagar, P.M. 1996. Diving depths of sooty shearwaters Puffinus griseus. Ibis 138(4): 786-788. doi:10.1111/j.1474-919X.1996.tb08837.x.

Wiens, J.A. 1976. Population responses to patchy environments. Annu. Rev. Ecol. Syst. 7: 81120.

Wiens, J.A., and Scott, J.M. 1975. Model estimation of energy flow in Oregon coastal seabird populations. The Condor 77(4): 439-452. doi:10.2307/1366091.

Wilson, C.D., Guttormsen, M.A., Cooke, K., Saunders, M.W., and Kieser, R. 2000. Echo integration-trawl survey of Pacific hake, Merluccius productus, off the Pacific coast of the United States and Canada during July-August 1998. NOAA Tech. Memo NMFSAFSC-118, 103 p.

Woillez, M., Poulard, J.-C., Rivoirard, J., Petitgas, P., and Bez, N. 2007. Indices for capturing spatial patterns and their evolution in time, with application to European hake 
985 986

987 988 989 990 991 992 993 994 995 996 997 998 999

1000

1001

1002

1003 (Merluccius merluccius) in the Bay of Biscay. ICES J. Mar. Sci. 64(3): 537-550. doi:10.1093/icesjms/fsm025.

Woillez, M., Rivoirard, J., and Fernandes, P.G. 2009. Evaluating the uncertainty of abundance estimates from acoustic surveys using geostatistical simulations. ICES J. Mar. Sci. 66(6): 1377-1383. doi:10.1093/icesjms/fsp137.

Yen, P.P.W., Sydeman, W.J., Bograd, S.J., and Hyrenbach, K.D. 2006. Spring-time distributions of migratory marine birds in the southern California Current: Oceanic eddy associations and coastal habitat hotspots over 17 years. Deep Sea Res. Part II Top. Stud. Oceanogr. 53(3-4): 399-418. doi:10.1016/j.dsr2.2006.01.013.

Zamon, J.E., Phillips, E.M., and Guy, T.J. 2014. Marine bird aggregations associated with the tidally-driven plume and plume fronts of the Columbia River. Deep Sea Res. Part II Top. Stud. Oceanogr. 107: 85-95. doi:10.1016/j.dsr2.2013.03.031.

Zar, J.H. 1999. Biostatistical analysis, 4th ed. Prentice Hall, Upper Saddle River, New Jersey.

Zuur, A.F., Ieno, E.N., Walker, N., Saveliev, A.A., and Smith, G.M. 2009. Mixed effects models and extensions in ecology with R. Springer, New York, New York.

Zwolinski, J.P., Demer, D.A., Byers, K.A., Cutter, G.R., Renfree, J.S., Sessions, T.S., and Macewicz, B.J. 2012. Distributions and abundances of Pacific sardine (Sardinops sagax) and other pelagic fishes in the California Current Ecosystem during spring 2006, 2008, and 2010, estimated from acoustic-trawl surveys. Fish Bull 110: 110-122. 
1006 effort, and mean river flow and plume volume during each survey.

1007

\begin{tabular}{|c|c|c|c|c|c|c|c|c|c|c|c|}
\hline Year & Month & Vessel & Date range & Echosounder & $\begin{array}{l}\text { Sound } \\
\text { speed } \\
\left(\mathrm{m} \mathrm{s}^{-1}\right)\end{array}$ & $\begin{array}{c}\text { Absorption } \\
\text { coefficient } \\
\left(\mathrm{dB} \mathrm{m}^{-1}\right)\end{array}$ & $\begin{array}{c}\text { Total } \\
\text { stations } \\
\text { sampled }\end{array}$ & $\begin{array}{c}\text { Total } \\
\text { surface } \\
\text { trawls }\end{array}$ & $\begin{array}{c}\text { Km } \\
\text { survey } \\
\text { effort }^{\mathrm{a}}\end{array}$ & $\begin{array}{c}\text { Mean } \\
\text { river flow } \\
\left(1000 \mathrm{~m}^{3}\right. \\
\left.\mathrm{s}^{-1}\right) \\
\end{array}$ & $\begin{array}{c}\text { Mean } \\
\text { plume } \\
\text { volume } \\
\left(\mathrm{km}^{3}\right)\end{array}$ \\
\hline \multirow[t]{2}{*}{2010} & May & Chellissa & $5 / 21-5 / 27$ & - & - & - & 41 & 39 & 201.3 & 8.7 & 10.8 \\
\hline & June & Frosti & $6 / 21-6 / 28$ & ES60 & 1493.89 & 0.008047 & 57 & 55 & 275.5 & 11.0 & 11.3 \\
\hline \multirow[t]{2}{*}{2011} & May & Frosti & $5 / 21-5 / 27$ & ES60 & 1480.49 & 0.008302 & 50 & 48 & 223.1 & 16.3 & 51.9 \\
\hline & June & Frosti & $6 / 20-6 / 27$ & ES60 & 1480.49 & 0.008302 & 57 & 56 & 272.7 & 15.0 & 38.7 \\
\hline \multirow[t]{2}{*}{2012} & May & Miss Sue & $5 / 30-6 / 3$ & EK60 & 1482.94 & 0.009835 & 45 & 32 & 145.8 & 10.2 & 33.1 \\
\hline & June & Frosti & $6 / 21-6 / 28$ & ES60 & 1479.80 & 0.009101 & 53 & 50 & 262.1 & 12.4 & 16.0 \\
\hline
\end{tabular}

${ }^{a}$ line transect survey effort only; excludes trawl distances 


\begin{tabular}{|c|c|c|c|c|c|c|c|c|c|c|}
\hline \multirow[b]{2}{*}{ Common Name } & \multirow[b]{2}{*}{ Scientific Name } & \multirow[b]{2}{*}{ Total } & \multirow[b]{2}{*}{$\%$ of Total } & \multirow[b]{2}{*}{ FO } & \multicolumn{2}{|c|}{2010} & \multicolumn{2}{|c|}{2011} & \multicolumn{2}{|c|}{2012} \\
\hline & & & & & May & June & May & June & May & June \\
\hline Sooty shearwater & Ardenna grisea & 5181 & 50.62 & 1.0 & 606 & 3108 & 449 & 353 & 282 & 383 \\
\hline Common murre & Uria aalge & 3526 & 34.45 & 1.0 & 629 & 1632 & 267 & 441 & 255 & 302 \\
\hline Pink-footed shearwater & Ardenna creatopus & 815 & 7.96 & 1.0 & 16 & 242 & 15 & 324 & 3 & 215 \\
\hline Dark shearwater (unid.) & Ardenna spp. & 189 & 1.85 & 0.5 & 87 & 93 & - & - & - & 9 \\
\hline Rhinoceros auklet & Cerorhinca monocerata & 141 & 1.38 & 1.0 & 12 & 63 & 52 & 8 & 4 & 2 \\
\hline Black-footed albatross & Phoebastria nigripes & 77 & 0.75 & 0.7 & - & 14 & - & 61 & 1 & 1 \\
\hline Phalarope (unid.) & Phalaropus spp. & 73 & 0.71 & 0.2 & - & - & 73 & - & - & - \\
\hline Cassin's auklet & Ptychoramphus aleuticus & 51 & 0.50 & 0.8 & 5 & - & 15 & 2 & 6 & 23 \\
\hline Western $\times$ glaucous-winged gull & Larus occidentalis $x$ glaucescens & 47 & 0.46 & 0.8 & 1 & 35 & 1 & 5 & - & 5 \\
\hline Gull (unid.) & Larus spp. & 37 & 0.36 & 0.8 & 12 & 3 & 18 & 3 & 1 & - \\
\hline Pacific loon & Gavia pacifica & 23 & 0.22 & 0.7 & 5 & 2 & 12 & 4 & - & - \\
\hline Ancient murrelet & Synthliboramphus antiquus & 10 & 0.10 & 0.5 & 3 & - & 4 & - & 3 & - \\
\hline Northern fulmar & Fulmarus glacialis & 10 & 0.10 & 0.5 & - & 3 & 1 & 6 & - & - \\
\hline Marbled murrelet & Brachyramphus marmoratus & 8 & 0.08 & 0.5 & - & 4 & - & 2 & - & 2 \\
\hline Alcid (unid.) & Alcidae & 7 & 0.07 & 0.3 & 1 & - & 6 & - & - & - \\
\hline Red-necked phalarope & Phalaropus lobatus & 6 & 0.06 & 0.2 & 6 & - & - & - & - & - \\
\hline Immature gull (unid.) & Larus spp. & 6 & 0.06 & 0.5 & 1 & - & 3 & 2 & - & - \\
\hline Double-crested cormorant & Phalacrocorax auritus & 5 & 0.05 & 0.7 & - & 1 & 1 & 2 & - & 1 \\
\hline Western gull & Larus occidentalis & 4 & 0.04 & 0.2 & - & - & - & - & - & 4 \\
\hline Brown pelican & Pelecanus occidentalis & 3 & 0.03 & 0.2 & - & - & - & - & - & 3 \\
\hline Tufted puffin & Fratercula cirrhata & 3 & 0.03 & 0.3 & - & 1 & 2 & - & - & - \\
\hline Scoter (unid.) & Melanitta spp. & 3 & 0.03 & 0.2 & - & - & 3 & - & - & - \\
\hline Pelagic cormorant & Phalacrocorax pelagicus & 2 & 0.02 & 0.3 & - & 1 & - & 1 & - & - \\
\hline Cormorant (unid.) & Phalacrocorax spp. & 2 & 0.02 & 0.2 & - & 2 & - & - & - & - \\
\hline
\end{tabular}


Running page head: Predator-prey interactions river plume

Brandt's cormorant

Common loon

Glaucous-winged gull

Red-throated loon

Ring-billed gull

South Polar skua

Western grebe

Total
Phalacrocorax penicillatus

Gavia immer

Larus glaucescens

Gavia stellata

Larus delawarensis

Catharacta maccormicki

Aechmophorus occidentalis

1011

1012 


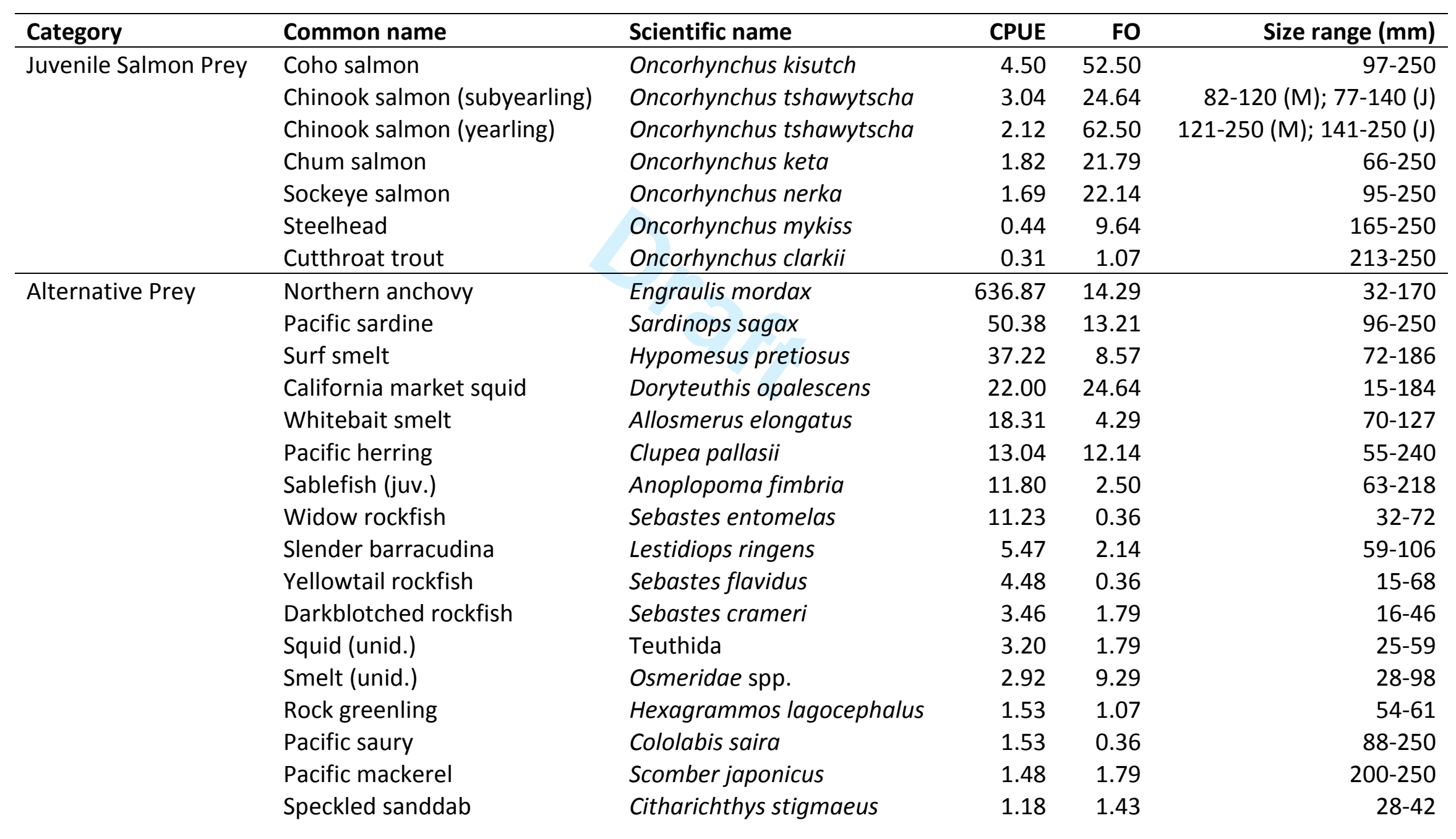


Running page head: Predator-prey interactions river plume

\begin{tabular}{|c|c|c|c|c|c|}
\hline & Pacific sand lance & Ammodytes hexapterus & 1.01 & 3.93 & $34-61$ \\
\hline & Shortbelly rockfish & Sebastes jordani & 0.91 & 0.71 & $35-41$ \\
\hline & Canary rockfish & Sebastes pinniger & 0.85 & 1.07 & $21-35$ \\
\hline & Rex sole & Glyptocephalus zachirus & 0.76 & 0.36 & $62-68$ \\
\hline & Lingcod & Ophiodon elongatus & 0.53 & 0.71 & $43-58$ \\
\hline & Sanddab (unid.) & Citharichthys spp. & 0.32 & 0.36 & 45 \\
\hline & Pacific sandfish & Trichodon trichodon & 0.32 & 0.36 & 212 \\
\hline & Pacific tomcod & Microgadus proximus & 0.29 & 1.79 & $37-51$ \\
\hline & American shad & Alosa sapidissima & 0.29 & 0.71 & $179-205$ \\
\hline & Medusafish & Icichthys lockingtoni & 0.28 & 0.71 & $13-100$ \\
\hline & Shiner perch & Cymatogaster aggregata & 0.28 & 0.36 & 98 \\
\hline & Northern ronquil & Ronquilus jordani & 0.27 & 0.36 & 30 \\
\hline & Threespine stickleback & Gasterosteus aculeatus & 0.27 & 0.36 & 76 \\
\hline & Herring family & Clupeidae & 0.27 & 0.36 & 30 \\
\hline \multirow[t]{17}{*}{ Non-prey Biomass } & Sea nettle & Chrysaora fuscescens & 36.92 & 30.00 & $15-350$ \\
\hline & Spiny dogfish & Squalus acanthias & 32.71 & 8.21 & $50-1150$ \\
\hline & Water jelly & Aequorea spp. & 22.63 & 32.86 & $10-210$ \\
\hline & Pacific hake & Merluccius productus & 3.76 & 2.14 & $320-390$ \\
\hline & Cross jelly & Mitrocoma cellularia & 1.61 & 1.43 & $20-78$ \\
\hline & Steelhead & Oncorhynchus mykiss & 1.40 & 2.86 & $251-598$ \\
\hline & Comb jellies & Ctenophora & 0.89 & 34.29 & \\
\hline & Black rockfish & Sebastes melanops & 0.88 & 1.43 & $272-470$ \\
\hline & Pink salmon & Oncorhynchus gorbuscha & 0.82 & 0.71 & $465-489$ \\
\hline & Chinook salmon & Oncorhynchus tshawytscha & 0.80 & 52.14 & $251-870$ \\
\hline & Pacific sardine (>250 mm) & Sardinops sagax & 0.78 & 3.21 & $251-273$ \\
\hline & Pacific saury (>250 mm) & Cololabis saira & 0.70 & 0.71 & $251-305$ \\
\hline & Starry flounder & Platichthys stellatus & 0.54 & 4.64 & $230-560$ \\
\hline & Eggyolk jelly & Phacellophora camtschatica & 0.52 & 12.86 & $70-380$ \\
\hline & Coho salmon & Oncorhynchus kisutch & 0.52 & 38.21 & $251-712$ \\
\hline & Pacific staghorn sculpin & Leptocottus armatus & 0.50 & 2.14 & $170-265$ \\
\hline & Jack mackerel & Trachurus symmetricus & 0.50 & 1.79 & $523-690$ \\
\hline
\end{tabular}


Running page head: Predator-prey interactions river plume

\begin{tabular}{|c|c|c|c|c|}
\hline Moon jelly & Aurelia spp. & 0.45 & 8.21 & $65-355$ \\
\hline Wolf-eel & Anarrhichthys ocellatus & 0.44 & 12.50 & $260-605$ \\
\hline Blue shark & Prionace glauca & 0.38 & 1.79 & $520-1800$ \\
\hline Lion's mane jelly & Cyanea capillata & 0.36 & 1.43 & $120-300$ \\
\hline Soupfin shark & Galeorhinus zyopterus & 0.35 & 2.86 & $780-1758$ \\
\hline English sole & Parophrys vetulus & 0.34 & 0.36 & 300 \\
\hline Chum salmon & Oncorhynchus keta & 0.33 & 3.93 & 251-695 \\
\hline Cutthroat trout & Oncorhynchus clarkii & 0.32 & 1.07 & $251-400$ \\
\hline Salmon shark & Lamna ditropis & 0.30 & 0.36 & 1950 \\
\hline Pacific lamprey & Lampetra tridentata & 0.30 & 0.71 & $308-720$ \\
\hline Pacific mackerel (>250 mm) & Scomber japonicus & 0.29 & 0.71 & $251-282$ \\
\hline Butter sole & Isopsetta isolepis & 0.29 & 0.36 & 25 \\
\hline River lamprey & Lampetra ayresii & 0.28 & 2.14 & $258-330$ \\
\hline Yellowtail rockfish & Sebastes flavidus & 0.28 & 0.36 & 415 \\
\hline Widow rockfish & Sebastes entomelas & 0.28 & 0.36 & 386 \\
\hline Sockeye salmon & Oncorhynchus nerka & 0.28 & 0.71 & $251-465$ \\
\hline Jellyfish (unid.) & Scyphozoa spp. & 0.32 & 0.71 & 155 \\
\hline Penicillate jelly & Polyorchis penicillatus & 0.29 & 0.36 & $30-70$ \\
\hline Sea butterfly & Corolla spectabilis & 0.34 & 3.21 & - \\
\hline Salp (unid.) & Salpidae & 0.34 & 0.71 & - \\
\hline Beroe (unid.) & Beroe spp. & 0.33 & 0.71 & - \\
\hline Carinaria japonica & Carinaria japonica & 0.32 & 4.64 & - \\
\hline Hormiphora cucumis & Hormiphora cucumis & 0.32 & 26.79 & - \\
\hline Umbrella jelly & Eutonina indicans & 0.29 & 0.36 & - \\
\hline Sea gooseberry & Pleurobrachia spp. & 0.28 & 7.14 & - \\
\hline Clio pyramidata & Clio pyramidata & 0.28 & 0.36 & - \\
\hline Sea angel & Clione limacina & 0.26 & 0.36 & - \\
\hline
\end{tabular}

Table 4. Global index of collocation values between murres and shearwaters and the three most frequently caught juvenile salmon, 1016 and the six most abundant alternative prey fish species; darker shading indicates higher value of GIC and values $\geq 0.888$ were

1017 considered indicative of a relationship between predator and prey. 


\begin{tabular}{|c|c|c|c|c|c|c|c|}
\hline \multirow[b]{2}{*}{ Predator } & \multirow[b]{2}{*}{ Prey Species } & \multicolumn{2}{|c|}{2010} & \multicolumn{2}{|c|}{2011} & \multicolumn{2}{|c|}{2012} \\
\hline & & May & June & May & June & May & June \\
\hline \multirow[t]{9}{*}{ Common murre } & Chinook salmon (SY) & 0.879 & 0.361 & 0.940 & 0.423 & 0.418 & 0.876 \\
\hline & Chinook salmon $(\mathrm{Y})$ & 0.954 & 0.411 & 0.748 & 0.364 & 0.575 & 0.728 \\
\hline & Coho salmon & 0.988 & 0.387 & 0.713 & 0.429 & 0.663 & 0.805 \\
\hline & Northern anchovy & 0.670 & 0.856 & 0.847 & 0.809 & 0.196 & 0.939 \\
\hline & Pacific herring & 0.919 & 0.202 & 0.719 & 0.924 & 0.406 & 0.882 \\
\hline & Pacific sardine & 0.919 & 0.425 & 0.679 & 0.342 & 0.669 & 0.377 \\
\hline & Market squid & 0.933 & 0.567 & 0.579 & 0.629 & 0.488 & 0.906 \\
\hline & Surf smelt & 0.887 & 0.198 & 0.838 & 0.521 & 0.196 & 0.281 \\
\hline & Whitebait smelt & 0.484 & 0.106 & 0.182 & 0.609 & 0.484 & 0.983 \\
\hline \multirow[t]{9}{*}{ Sooty shearwater } & Chinook salmon (SY) & 0.777 & 0.982 & 0.400 & 0.996 & 0.815 & 0.972 \\
\hline & Chinook salmon $(\mathrm{Y})$ & 0.918 & 0.990 & 0.972 & 0.858 & 0.887 & 0.921 \\
\hline & Coho salmon & 0.771 & 0.977 & 0.977 & 0.891 & 0.937 & 0.973 \\
\hline & Northern anchovy & 0.971 & 0.511 & 0.220 & 0.605 & 0.468 & 0.651 \\
\hline & Pacific herring & 0.966 & 0.793 & 0.998 & 0.679 & 0.696 & 0.675 \\
\hline & Pacific sardine & 0.899 & 0.932 & 0.590 & 0.723 & 0.364 & 0.468 \\
\hline & Market squid & 0.659 & 0.889 & 0.940 & 0.928 & 0.776 & 0.611 \\
\hline & Surf smelt & 0.887 & 0.902 & 0.939 & 0.988 & 0.469 & 0.088 \\
\hline & Whitebait smelt & 0.270 & 0.604 & 0.348 & 0.066 & 0.880 & 0.881 \\
\hline
\end{tabular}


Table 5. Variables used in generalized linear models, including variable type and measurement, abbreviation used to describe covariates in the final models, the models in which each variable was included, and median, range, mean and standard deviation of the measurements.

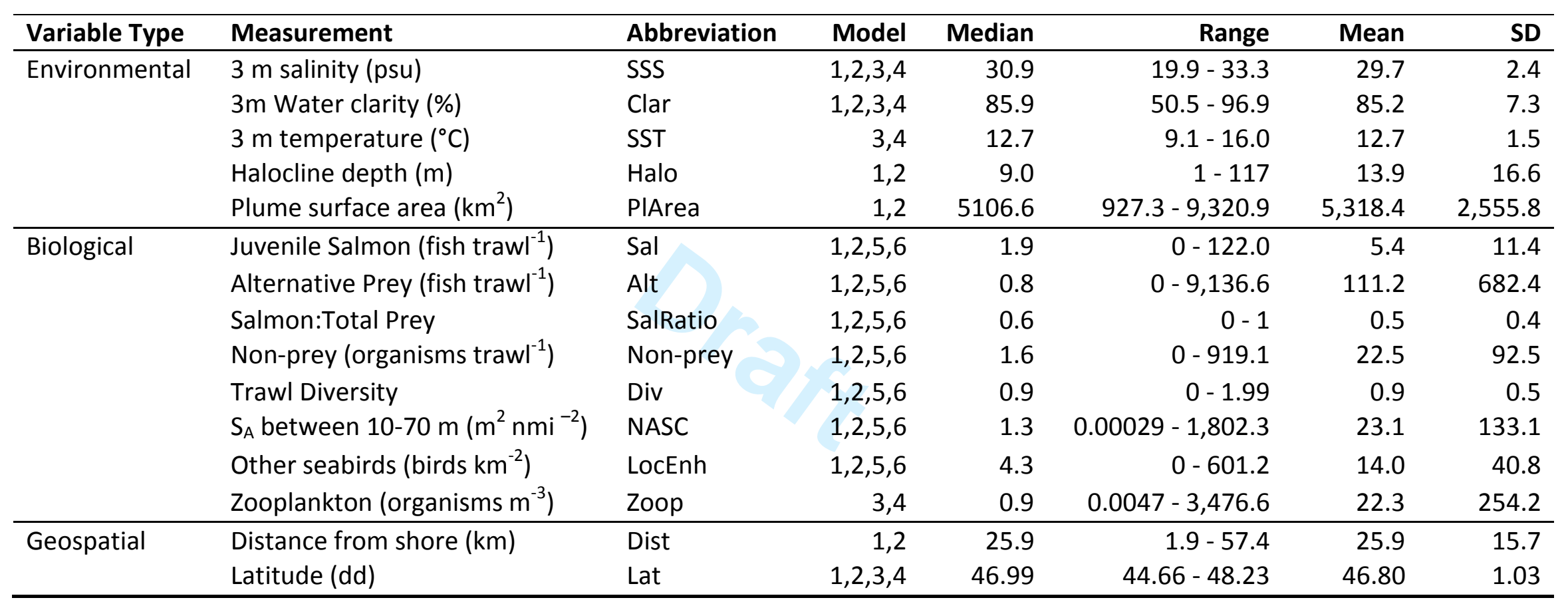


Table 6. Generalized linear model results for predator (murre and shearwater) and prey (juvenile salmon and alternative prey) densities throughout the survey region, and predators within the river plume. Final models presented include slope and parameter estimates for significant covariates, AICc, and model weight.

\begin{tabular}{|c|c|c|}
\hline Model & Final Model Equation & Weight \\
\hline 1: Murre density throughout region & $44.7+-0.03($ Clar) $+0.0081($ LocEnh) +-0.000037 (NASC) +-0.10 (Dist) +-0.83 (Lat) & 1.00 \\
\hline 2: Shearwater density throughout region & $7.5+-0.063($ Clar $)+0.001($ LocEnh $)+-0.0031$ (NASC) & 0.94 \\
\hline 3: Alternative prey throughout region & $12.3+-0.084($ Clar $)+-0.11$ (Zoop) & 0.38 \\
\hline 5: Murre density in plume & $1.6+-1.36$ (SalRatio) + 0.0062(Non-prey) + 1.01(Div) & 0.95 \\
\hline 6: Shearwater density in plume & $1.3++0.025($ Sal $)+-0.0022($ Alt $)+1.54($ SalRatio $)+-0.025($ NASC $)$ & 0.93 \\
\hline
\end{tabular}


1032

1033

1034

1035

1036

1037

1038

1039

1040

1041

1042

1043

1044

1045

1046

1047

1048 1049 indicate disproportionate occurrence in the plume.

\section{Figure Captions}

Figure 1. Map of study area, including line transects and oceanographic sampling stations along the Oregon and Washington coasts. Each transect line is named for a geographic feature in proximity to the inshore end of the line as follows: $\mathrm{FS}=$ Father and $\mathrm{Son}, \mathrm{LP}=\mathrm{La}$ Push, $\mathrm{QR}=$ Queets River, $\mathrm{GH}=$ Grays Harbor, $\mathrm{WB}=$ Willapa Bay, $\mathrm{CR}=$ Columbia River, $\mathrm{CM}=$ Cape

Meares, and $\mathrm{NH}=$ Newport Hydrographic. Murre colonies along the coast are shown as yellow circles with circle size representing estimated colony size based on count data from U.S. Fish and Wildlife Service. Map created using ArcGIS ${ }$ software by Esri.

Figure 2. Average daily Columbia River flow in 2010, 2011, 2012, and 10 y average (2002 2012) measured at U.S. Geological Survey surface water station 14246900.

Figure 3. Area use of the Columbia River plume by seabirds and prey fish in each survey. Use was calculated by subtracting the observed proportions of seabirds and prey in the plume from expected proportions, defined as the proportion of plume area in the total calculated survey area during each cruise. If seabirds and prey were using the plume proportionate to available area, then differences between observed and expected values would be zero. Values greater than zero

1051 Figure 4. The relationship between a) mean plume surface area $( \pm$ SE) and density of common 1052 murres in the plume, and mean plume volume $( \pm \mathrm{SE})$ and $b)$ shearwaters in the plume, $c)$ prey 1053 fish densities in the plume measured by surface trawl and d) acoustic backscatter in the plume. 
Running page head: Predator-prey interactions river plume

1055 Figure 5. Distribution of the interpolated plume surface area, centers of gravity, and axes of 1056 inertia of predators and prey in 2010, 2011, and 2012 in May (top panels) and June (bottom 1057 panels). Maps created using ArcGIS® software by Esri. 
Running page head: Predator-prey interactions river plume

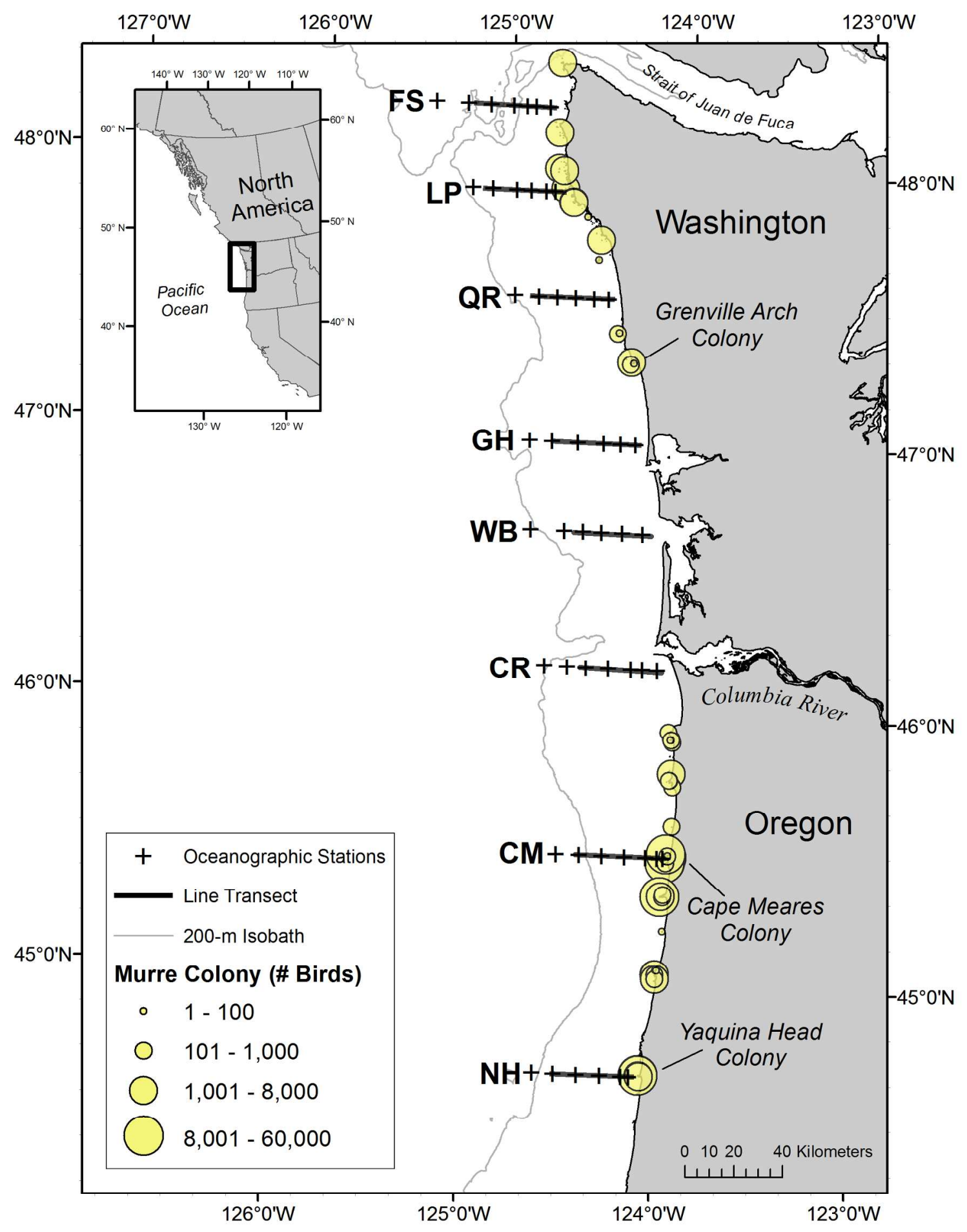

1059 Figure 1. Map of study area, including line transects and oceanographic sampling stations along 1060 the Oregon and Washington coasts. Each transect line is named for a geographic feature in 
Running page head: Predator-prey interactions river plume

1061 proximity to the inshore end of the line as follows: FS = Father and Son, $\mathrm{LP}=\mathrm{La}$ Push, $\mathrm{QR}=$ 1062 Queets River, GH = Grays Harbor, WB = Willapa Bay, CR = Columbia River, CM= Cape

1063 Meares, and NH = Newport Hydrographic. Murre colonies along the coast are shown as yellow

1064 circles with circle size representing estimated colony size based on count data from U.S. Fish 1065 and Wildlife Service. Map created using ArcGIS $®$ software by Esri. 


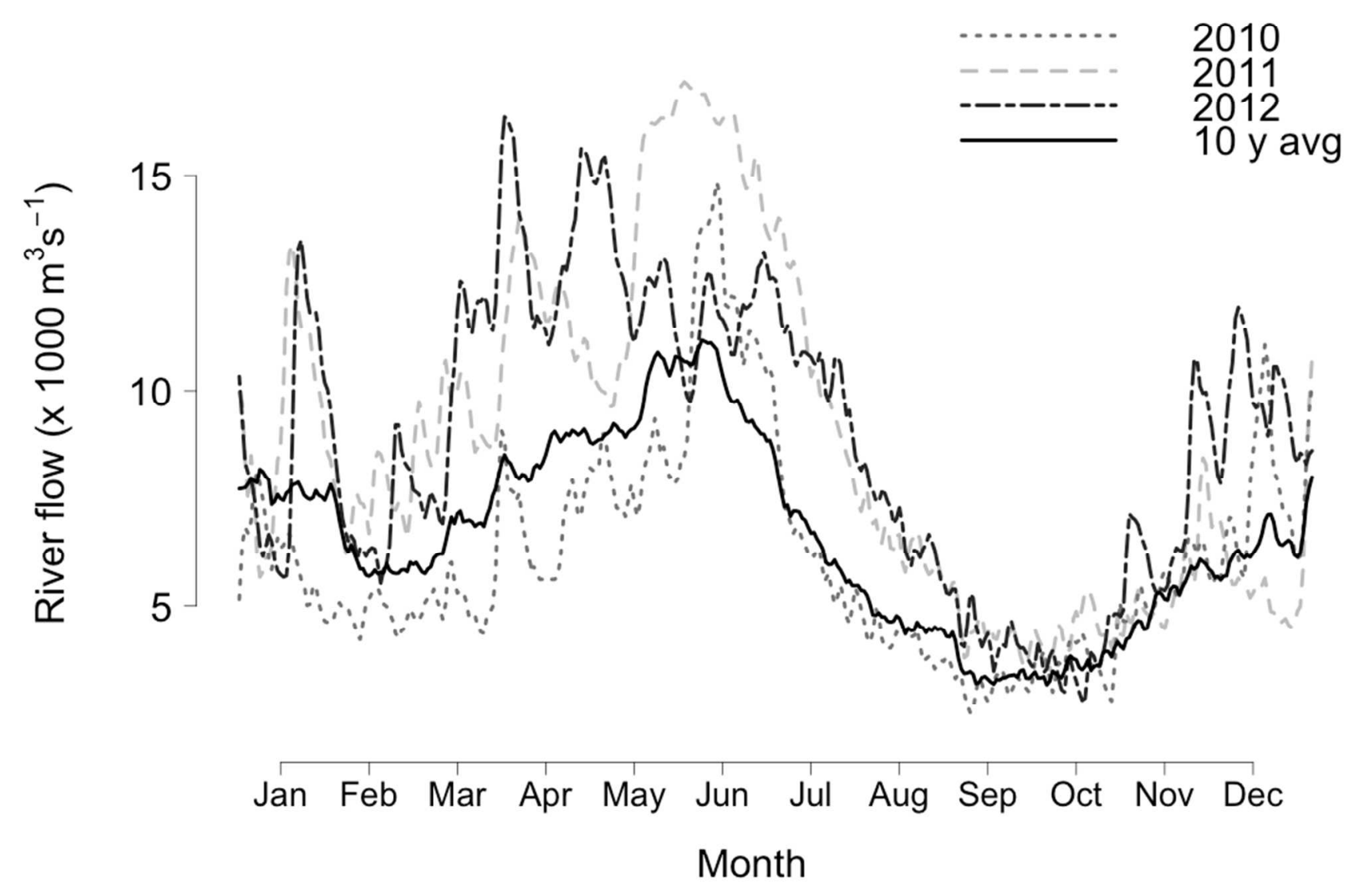

1066

1067 Figure 2. Average daily Columbia River flow in 2010, 2011, 2012, and 10 y average (2002 - 2012) measured at U.S. Geological 1068 Survey surface water station 14246900. 
Running page head: Predator-prey interactions river plume

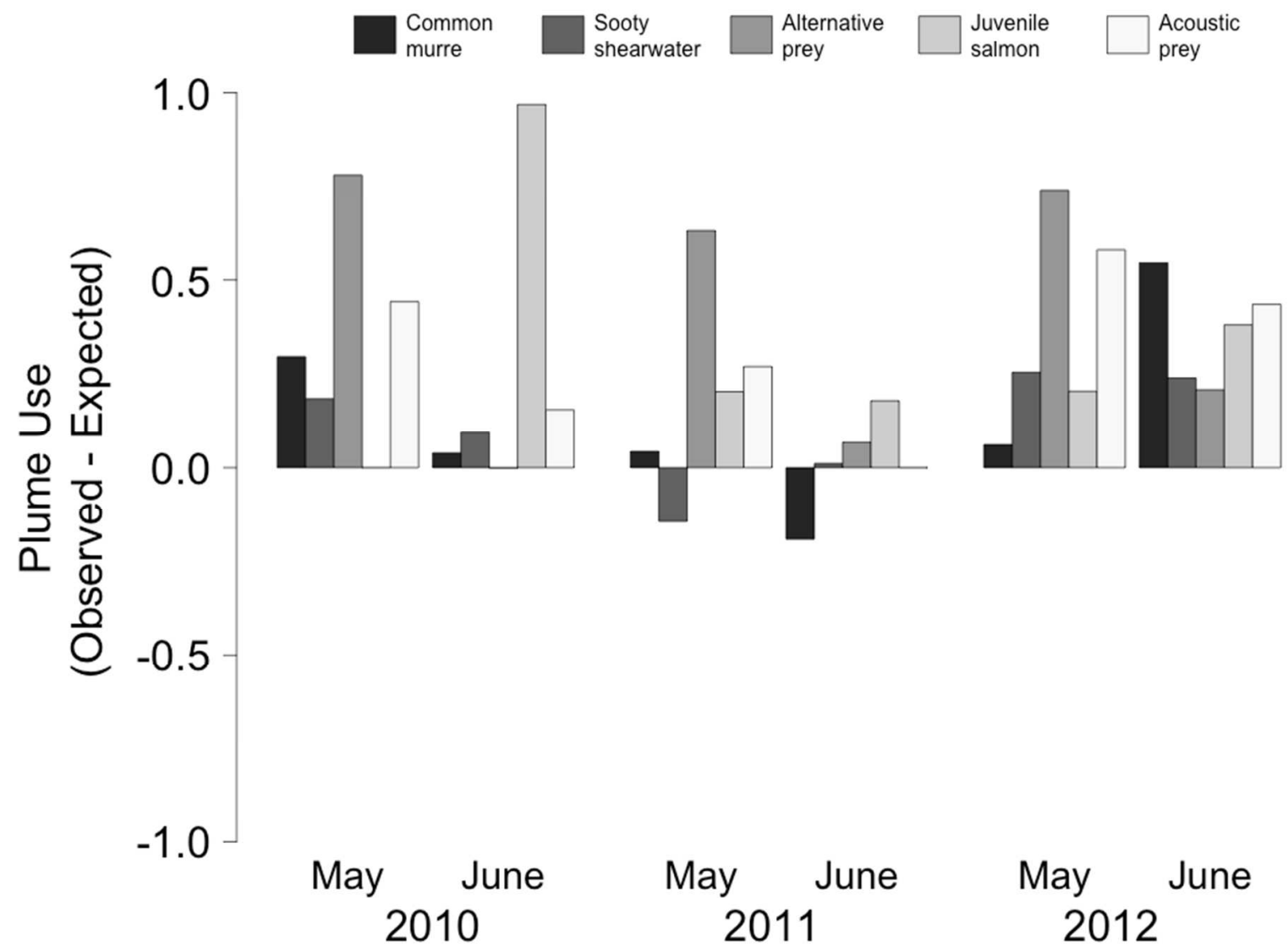

1070 Figure 3. Area use of the Columbia River plume by seabirds and prey in each survey. Use was calculated by subtracting the observed

1071 proportions of seabirds and prey in the plume from expected proportions, defined as the proportion of plume area in the total 
Running page head: Predator-prey interactions river plume

1072 calculated survey area during each cruise. If seabirds and prey were using the plume proportionate to available area, then differences

1073 between observed and expected values would be zero. Values greater than zero indicate disproportionate occurrence in the plume. 
Running page head: Predator-prey interactions river plume
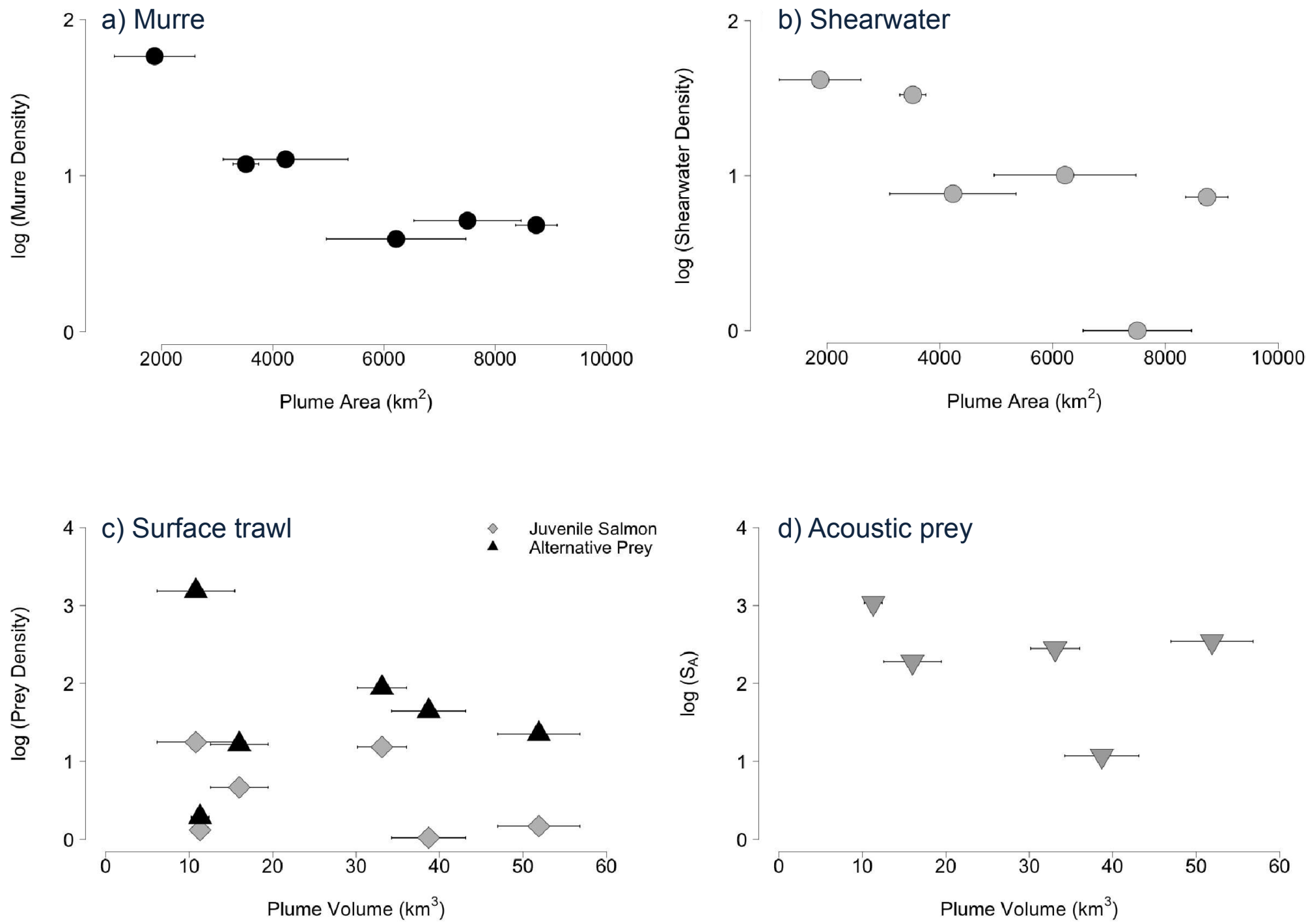
Running page head: Predator-prey interactions river plume

1075 Figure 4. The relationship between mean plume surface area or volume ( \pm SE) and density of a) common murres, b) shearwaters, c) 1076 prey fish densities measured by surface trawl, and d) acoustic backscatter in the plume. 

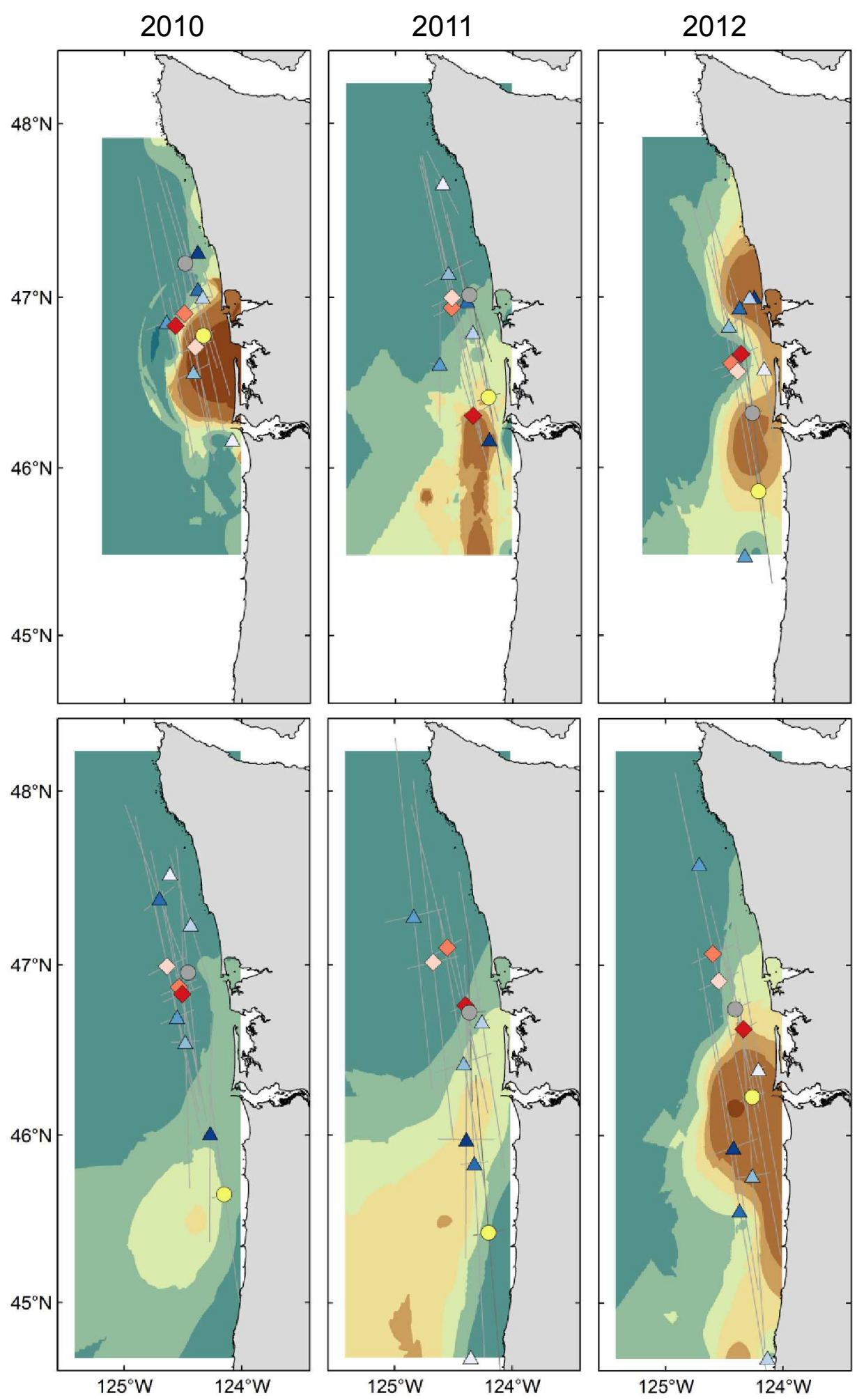

Predator Species

Common murre

Sooty shearwater

Prey Species

Chinook salmon (SY)

Chinook salmon (Y)

$\checkmark$ Coho salmon

A Northern anchovy

$\triangle$ Pacific herring

$\triangle$ Pacific sardine

$\triangle$ Market squid

$\triangle$ Surf smelt

$\triangle$ Whitebait smelt

Salinity (psu)

$0-21$

$21-26$

$26-27$

$27-28$

$28-29$

$29-30$

$30-32.5$

$32.5-34$ 
1079 Figure 5. Distribution of the interpolated plume surface area, centers of gravity, and axes of 1080 inertia of predators and prey in 2010, 2011, and 2012 in May (top panels) and June (bottom 1081 panels). Maps created using ArcGIS ${ }^{\circledR}$ software by Esri. 